\title{
A green multicomponent synthesis of Tocopherol analogues with
}

\section{antiproliferative activities}

Mariana Ingold $^{a}$, Rosina Dapueto $^{a}$, Sabina Victoria ${ }^{b}$, Germán Galliussi $^{c}$, Carlos Batthyàny

c, Mariela Bollati-Fogolín ${ }^{b}$, David Tejedor ${ }^{d}$, Fernando García-Tellado ${ }^{d}$, José M. Padrón ${ }^{e}$, Williams Porcal ${ }^{f *}$, Gloria. V. López ${ }^{a, f^{*}}$.

${ }^{a}$ Grupo de Química Medicinal, Laboratorio de Química Orgánica, Facultad de Ciencias-Facultad de Química, Universidad de la República, Iguá 4225, 11400, Montevideo, Uruguay. ${ }^{b}$ Cell Biology Unit, Institut Pasteur Montevideo, Mataojo 2020, 11400 Montevideo, Uruguay. ${ }^{c}$ Analytical Biochemistry and Proteomics Unit, Institut Pasteur Montevideo, Mataojo 2020, 11400, Montevideo, Uruguay. ${ }^{d}$ Instituto de Productos Naturales y Agrobiología, Consejo Superior de Investigaciones Cientificas, C/Astrofisico Francisco Sánchez 3, 38206 La Laguna, Spain. ${ }^{e}$ Instituto Universitario de Bio-Orgánica “Antonio González” (IUBO-AG), Centro de Investigaciones Biomedicas de Canarias (CIBICAN), Universidad de La Laguna, C/ Astrofisico Francisco Sánchez 2, 38200 La Laguna, Spain. ${ }^{f}$ Departamento de Química Orgánica, Facultad de Química, Universidad de la República, Av. General Flores 2124, 11800, Montevideo, Uruguay.

Abstract: A one-pot efficient, practical and eco-friendly synthesis of tocopherol analogues has been developed using water or solvent free conditions via Passerini and Ugi multicomponent reactions. These reactions can be optimized using microwave irradiation or ultrasound as the energy source. Accordingly, a small library of 30 compounds was prepared for biological tests. The evaluation of the antiproliferative activity in the human solid tumor cell lines A549 (lung), HBL-100 (breast), HeLa (cervix), SW1573 (lung), T-47D (breast), and WiDr (colon) provided lead compounds with $\mathrm{GI}_{50}$ values between 1-5 $\mu \mathrm{M}$. A structureactivity relationship is also discussed. One of the studied compounds comes up as a future candidate for the development of potent tocopherol-mimetic therapeutic agents for cancer.

Keywords: multicomponent reactions, green conditions, water, microwaves, ultrasound, antiproliferative 
Corresponding author. Tel.: + 5982 525-8618 ext. 7216; fax: + 598 2 525-0740; e-mail: vlopez@,fq.edu.uy

Corresponding author. Tel.: + 5982 9247881; fax: + 5982 924-1906; e-mail: wporcal@,fq.edu.uy

\section{Introduction}

Atherosclerosis and cancer are two of the most common causes of death in the world, mainly in developed countries $[1,2]$. Recently, common series of molecular pathways have emerged with a significant role in the pathogenesis and progression of both pathologies $[3,4]$. New and more effective drugs are needed for the treatment of such conditions. In this sense, over the past few years the potential anti-atherosclerotic activity of vitamin $\mathrm{E}$ analogues has been extensively investigated $[5,6]$. Surprisingly, recent studies indicate that these bioactive molecules may also exert antiproliferative activities. Tocopherols have been previously investigated as possible anticancer agents [7-10]. $\alpha$-Tocopherol and $\gamma$-tocopherol were found to inhibit the proliferation of human breast cancer and prostate cancer cells, respectively [11, 12]. Tocopherol metabolites, namely 2-(2'-carboxyethyl)-6-hydroxychromans ( $\alpha$ and $\gamma$ CEHC, Figure 1) and trolox (6-hydroxy-2,5,7,8-tetramethylchromancarboxylic acid), a watersoluble vitamin E analogue (Figure 1), have been shown to exert the same inhibitory effect on prostate cancer cell proliferation as the corresponding tocopherols $\left(\mathrm{IC}_{50}\right.$ approximately 5-50 $\mu \mathrm{M}$ on PC3 cell proliferation) [7]. Regarding tocopherol analogues, several tocopherolthiazolidinedione hybrid compounds have been shown to possess anticancer properties in vitro and in vivo. Particularly, troglitazone (Figure 1) presented antiproliferative activity in several cancer cell lines $[13,14]$. On the other hand, hybrid molecules combining tocopherol derivatives and nitric oxide releasing moieties (NO-donors) have been developed and promising antioxidant activities were obtained [15-17]. Nitric oxide ( $\mathrm{NO})$ is an important cellular messenger involved in many physiological processes such as immune responses, neurotransmission and vascular relaxation. Recently, several NO-donor hybrid compounds 
with strong antiproliferative activity have been reported [18-20]. High concentrations of $\mathrm{NO}$ could be generated by NO-donors like furoxans (1,2,5-oxadiazole $N$-oxide) and organic nitrates. Therefore, it is interesting to develop tocopherol analogue-NO donor derivatives with improved antiproliferative activities. In this context, our research is focused on the development of a fast, efficient and eco-friendly methodology towards the synthesis of tocopherol analogues to evaluate their antiproliferative activity against human solid tumor cells. To this end, we use a diversity-oriented synthesis (DOS) approach. A central goal of DOS is to create collections of structurally and stereochemically diverse molecules for evaluation in biological systems, hoping that a broader spectrum of diversity in the chemical library will lead to the generation of more information from biological screens [21, 22]. Of special interest are compounds that possess those molecular skeletons found in natural products and drug-like molecules $[23,24]$. One of the most promising synthetic strategies for generating collections of small molecules by DOS involves multicomponent reactions (MCRs), since they offer greater possibilities for molecular diversity per step with a minimum of synthetic effort, time and formation of by-products, high atom economies and limited numbers of synthetic steps $[25,26]$. These key points represent standards of green chemistry and characteristics of an ideal synthesis. We have recently studied the Passerini reaction, a three-component MCR where an aldehyde, a carboxylic acid and an isocyanide are involved to generate an $\alpha$-acyloxycarboxamide derivative, under green chemistry conditions [27]. From our studies, it was concluded that the Passerini three-component (3-CR) reaction between a furoxan aldehyde (NO-donor), phenylethyl isocyanide and trolox, can be efficiently carried out without solvent or in aqueous conditions, under microwave irradiation. Therefore, the combination of green conditions and MCRs represents a very efficient method from both economic and environmental perspectives. Therefore, Passerini three component and Ugi four component (4-CR) coupling reactions can be used to assemble a complex product from 
simple starting materials in a single step [28]. Herein, we report our study focused on these multicomponent reactions in water or solvent free conditions, at room temperature or using microwave irradiation or ultrasound as eco-friendly energy sources.

In brief, here we describe a one-pot green synthesis of tocopherol analogues, some of which incorporate NO-releasing moieties in its structure, and its in vitro activity (such as growth inhibition, apoptosis and cell cycle distribution) against a broad panel of human solid tumor cells.

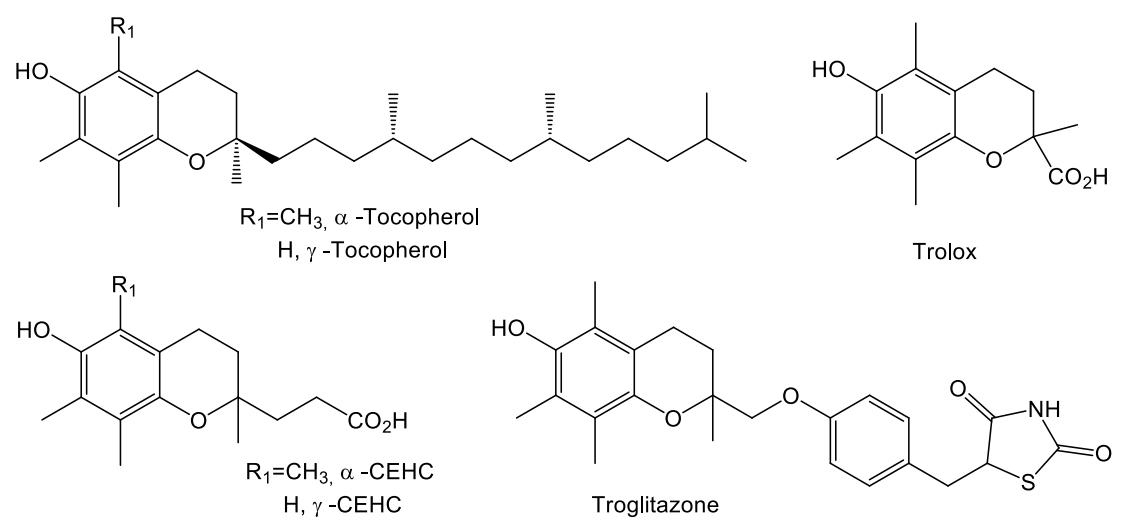

Figure 1. Structures of tocopherol and tocopherol analogues with antiproliferative activities.

\section{Results and discussion}

\subsection{Chemistry}

In order to generate a chemo-library of novel tocopherol analogues containing NO-donors through an eco-friendly one-pot reaction (Passerini and Ugi reactions), we first synthesized $(R, S)$-6-hydroxy-2,5,7,8-tetramethylchromancarboxylic acid methyl ester 1a [27] and its derivatives 1b-d and 2a-e, according to the synthetic routes illustrated in Scheme 1. Synthetic routes were design minimizing the use of reagents and solvents harmful to the environment. Firstly, methyl ester 1a and its derivatives $\mathbf{2 a}$ and $\mathbf{2 b}$ were prepared as previously reported [27]. The phenol group of 1a was protected either as methyl ether (1b), benzyl ether (1c) or Boc (1d) and as the corresponding methyl ester derivatives were hydrolyzed to the desired 
carboxylic acids 2c-e, which were used as the carboxylic component for the Passerini and Ugi reactions. The amine and isocyanide Ugi-components were obtained from commercial sources except for phenylethylisocyanide, which was prepared in our laboratory [27]. The aldehydes 3-6 that incorporate the NO-donors fragments (furoxan system or organic nitrate) in the final product (Figure 2) were chosen as aldehyde component [18, 29-33].

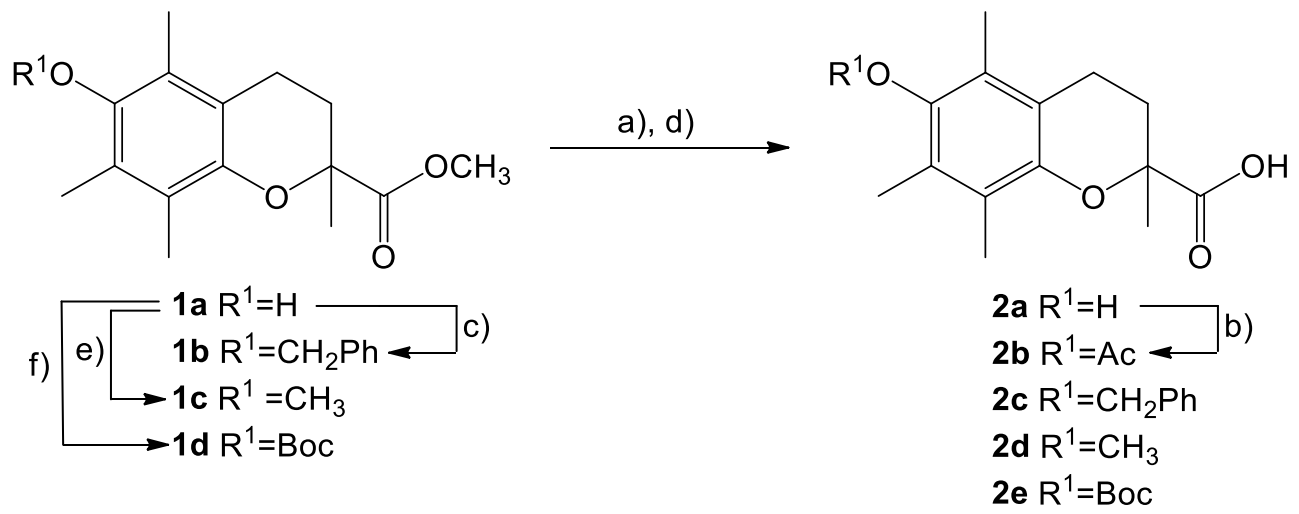

Scheme 1. $2 \mathbf{b}\left(\mathrm{R}^{1}=\mathrm{Ac}\right)$ : a) i) 1a, $\mathrm{NaOH}, \mathrm{MeOH}, 80^{\circ} \mathrm{C}$; ii) $\mathrm{KHSO}_{4}$ (aq), $80^{\circ} \mathrm{C}, 65 \%$; b) $\mathrm{Ac} 2 \mathrm{O}$, Py, rt, $2 \mathrm{~h}, 80 \%$; $2 \mathbf{c}$ $\left(\mathrm{R}^{1}=\mathrm{CH}_{2} \mathrm{Ph}\right)$ : c) 1a, $\mathrm{BrCH}_{2} \mathrm{Ph}, \mathrm{K}_{2} \mathrm{CO}_{3}$, DMF, $115^{\circ} \mathrm{C}, 11 \mathrm{~h}, 88 \%$; d) $\mathrm{LiOH} \cdot \mathrm{H}_{2} \mathrm{O}, \mathrm{EtOH}: \mathrm{H}_{2} \mathrm{O}$, rt, 24 h, $85 \%$; $2 \mathbf{d}$ $\left(\mathrm{R}^{1}=\mathrm{CH}_{3}\right)$ : e) 1a, DMC, DBU, TBAI, $90{ }^{\circ} \mathrm{C}(\mathrm{MW}), 1.5 \mathrm{~h}, 60 \%$; d) LiOH. $\mathrm{H}_{2} \mathrm{O}, \mathrm{EtOH}: \mathrm{H}_{2} \mathrm{O}, \mathrm{rt}, 24 \mathrm{~h}, 75 \%$; $2 \mathrm{e}$ $\left(\mathrm{R}^{1}=\text { Boc): f) 1a, (Boc) }\right)_{2} \mathrm{O}$, DMAP, THF, rt, 24 h, 75\%; d) LiOH. $\mathrm{H}_{2} \mathrm{O}$, EtOH: $\mathrm{H}_{2} \mathrm{O}, \mathrm{rt}, 24$ h, 90\%.<smiles></smiles>

3<smiles></smiles>

4<smiles>O=Cc1cccc(OCCO[N+](=O)[O-])c1</smiles>

$5 \mathrm{n}=3$

$6 n=4$

Figure 2. Aldehyde derivatives used in the present work. They featured a NO-releasing moiety (furoxan or organic nitrate).

Table 1. Tocopherol-mimetics NO-donors synthetized via Passerini reaction under green conditions.<smiles>[R20]c1c(C)c(C)c2c(c1C)CCC(C)(C(=O)O)O2</smiles>

2a-c

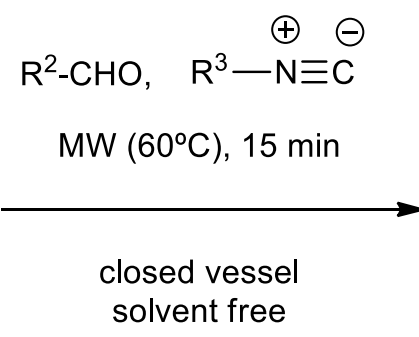

closed vesse solvent free<smiles>[R]NC(=O)C([R])OC(=O)C1(C)CCc2c(C)c([R10])c(C)c(C)c2O1</smiles>

7a-h 


\begin{tabular}{|c|c|c|c|c|}
\hline Compound & $\mathrm{R}^{1}$ & $\mathrm{R}^{2}$ & $\mathrm{R}^{3}$ & Yield (\%) \\
\hline $7 a$ & $\mathrm{H}$ & & $\mathrm{CH}_{2} \mathrm{CH}_{2} \mathrm{Ph}$ & $70^{\mathrm{a}}$ \\
\hline $7 b$ & Ac & & $\mathrm{CH}_{2} \mathrm{CH}_{2} \mathrm{Ph}$ & $46^{\mathrm{a}}$ \\
\hline $7 c$ & $\mathrm{Bn}$ & & $\mathrm{CH}_{2} \mathrm{CH}_{2} \mathrm{Ph}$ & $20^{\mathrm{b}}$ \\
\hline $7 d$ & $\mathrm{H}$ & & $\mathrm{CH}_{2} \mathrm{Ph}$ & 62 \\
\hline $7 e$ & $\mathrm{H}$ & O & $t$-butyl & 80 \\
\hline $7 f$ & $\mathrm{H}$ & & Cyclohexyl & 87 \\
\hline $7 \mathrm{~g}$ & $\mathrm{H}$ & & 2-morpholinoethyl & 9 \\
\hline $7 \mathrm{~h}$ & $\mathrm{H}$ & & $t$-butyl & 53 \\
\hline
\end{tabular}

${ }^{\mathrm{a}}$ Ingold, 2014 [27]. ${ }^{\mathrm{b}}$ green conditions tested: $\mathrm{H}_{2} \mathrm{O}, \mathrm{rt}, 4 \mathrm{~h}$.

Once tocopherol-mimetic starting materials were prepared, taking into account our previously experience in the Passerini reaction [27], we synthesized compounds 7a-h (Table 1) using aldehydes $\mathbf{3}$ and $\mathbf{4}$ to incorporate a NO-releasing moiety to the final structures. These $\alpha$ acyloxycarboxamide derivatives (Passerini products) were efficiently obtained using microwave irradiation under solvent-free conditions. The products were obtained in good to very good yields $(45-87 \%)$ and in short reaction times $(15 \mathrm{~min})$ at $60{ }^{\circ} \mathrm{C}$, except when the morpholinoethylisocyanide was used.

Besides, with the purpose of preparing a series of tocopherol-mimetics by the Ugi reaction, our preliminary efforts were mainly focused on the optimization of the reaction conditions. To this end, we carried out a model reaction of benzyl isocyanide $(0.6 \mathrm{mmol})$, benzaldehyde $(0.6$ mmol), aniline $(0.6 \mathrm{mmol})$ and 6-hydroxy-2,5,7,8-tetramethylchromancarboxylic acid $(0.6$ mmol) 2a using different green conditions summarized in Table 1S (See supporting information). Initially, the effect of microwave irradiation was examined under solvent free conditions (Table 1S, Entries 1 and 2) but lower yields were observed, and the Passerini 
product 7i was also obtained. In this context, taking into account that Pirrung and Das Sarma described a significant rate enhancement for the Ugi reaction when the organic solvent was replaced by water $[34,35]$, we decided to test the Ugi reaction in aqueous milieu under microwave heating or at room temperature. After considerable experimental work, an optimal experimental procedure was established for this reaction. In a $\mathrm{pH} 5.5$ buffer solution at room temperature the reaction was completed after $24 \mathrm{~h}$ with high yields (77\%, Table 2, Entry 1$)$. According to the widely accepted mechanism of the Ugi reaction, it involves protonation of the imine followed by nucleophilic addition of the isocyanide to the iminium ion, therefore, $\mathrm{pH} 5.5$ is an appropriate value for the formation of the iminium ion [36].

Table 2. Tocopherol-mimetics prepared by Ugi reaction under green conditions<smiles>[R20]c1c(C)c(C)c2c(c1C)CCC(C)(C(=O)O)O2</smiles>

2a-e

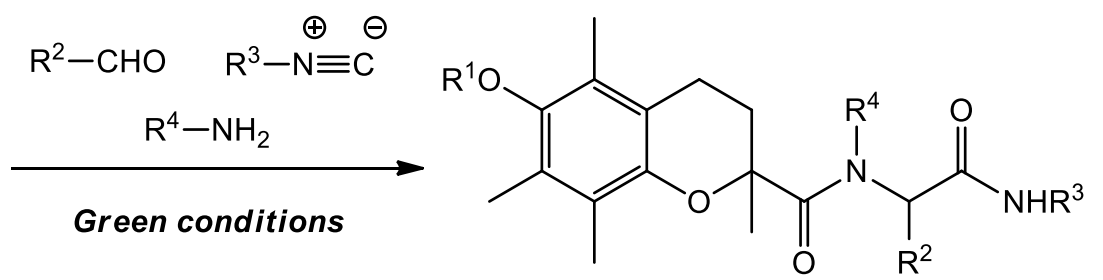

8a-s

\begin{tabular}{|c|c|c|c|c|c|c|}
\hline Entry & $\mathbf{R}^{1}$ & $\mathbf{R}^{2}$ & $\mathbf{R}^{3}$ & $\mathbf{R}^{4}$ & Conditions & $\begin{array}{l}\text { Product } \\
\text { (Yield) }\end{array}$ \\
\hline 1 & $\mathrm{H}$ & Phenyl & Benzyl & Phenyl & $\begin{array}{l}\text { pH } 5.5 \text { buffer aqueous } \\
\text { solution, rt, } 24 \text { h }\end{array}$ & $\mathbf{8 a}(77 \%)$ \\
\hline 2 & $\mathrm{H}$ & Phenyl & $t$-Butyl & Phenyl & $\begin{array}{c}\mathrm{pH} 5.5 \text { buffer aqueous } \\
\text { solution, rt, } 24 \mathrm{~h}\end{array}$ & $\mathbf{8 b}(77 \%)$ \\
\hline 3 & $\mathrm{H}$ & Phenyl & Cyclohexyl & Phenyl & $\begin{array}{l}\mathrm{pH} 5.5 \text { buffer aqueous } \\
\text { solution, } \mathrm{rt}, 24 \mathrm{~h}\end{array}$ & $8 c(60 \%)$ \\
\hline 4 & $\mathrm{H}$ & Pentyl & Benzyl & Phenyl & $\begin{array}{l}\mathrm{pH} 5.5 \text { buffer aqueous } \\
\text { solution, rt, } 24 \mathrm{~h}\end{array}$ & $8 d(41 \%)$ \\
\hline 5 & $\mathrm{H}$ & Pentyl & $t$-Butyl & Phenyl & $\begin{array}{c}\mathrm{pH} 5.5 \text { buffer aqueous } \\
\text { solution, rt, } 24 \mathrm{~h}\end{array}$ & $\mathbf{8 e}(47 \%)$ \\
\hline 6 & $\mathrm{H}$ & Pentyl & Cyclohexyl & Phenyl & $\begin{array}{c}\mathrm{pH} 5.5 \text { buffer aqueous } \\
\text { solution, rt, } 24 \mathrm{~h}\end{array}$ & $8 f(39 \%)$ \\
\hline 7 & $\mathrm{H}$ & Phenyl & Phenethyl & $\begin{array}{c}\mathrm{CH}_{2} \mathrm{CO}_{2} \\
\mathrm{Et}\end{array}$ & $\begin{array}{c}\mathrm{EtOH}, \\
\mathrm{MW}, 60^{\circ} \mathrm{C}, 45 \mathrm{~min}\end{array}$ & $8 g(61 \%)$ \\
\hline 8 & $\mathrm{H}$ & 3-(allyloxy)phenyl & Benzyl & Phenyl & $\begin{array}{l}\mathrm{pH} 5.5 \text { buffer aqueous } \\
\text { solution, rt, } 24 \mathrm{~h}\end{array}$ & $8 h(40 \%)$ \\
\hline 9 & $\mathrm{H}$ & 3-(allyloxy)phenyl & $t$-Butyl & Phenyl & Solvent free, US, $6 \mathrm{~h}$ & $8 \mathbf{i}(55 \%)$ \\
\hline 10 & $\mathrm{H}$ & 3-(allyloxy)phenyl & Cyclohexyl & Phenyl & $\begin{array}{c}\mathrm{pH} 5.5 \text { buffer aqueous } \\
\text { solution, US, } 6 \mathrm{~h}\end{array}$ & $\mathbf{8 j}(32 \%)$ \\
\hline 11 & $\mathrm{H}$ & 3-butenyl & $t$-Butyl & Phenyl & Solvent free, US, $6 \mathrm{~h}$ & $8 \mathbf{k}(51 \%)$ \\
\hline 12 & Boc & 3-butenyl & $t$-Butyl & Phenyl & Solvent free, US, $6 \mathrm{~h}$ & $81(99 \%)$ \\
\hline 13 & $\mathrm{H}$ & $\begin{array}{c}\text { 3-(3- } \\
\text { nitrooxypropyloxy) } \\
\text { phenyl (5) }\end{array}$ & Phenetyl & Phenyl & $\begin{array}{l}\mathrm{pH} 5.5 \text { buffer aqueous } \\
\text { solution, } \mathrm{rt}, 24 \mathrm{~h}\end{array}$ & $8 \mathbf{m}(29 \%)$ \\
\hline
\end{tabular}




\begin{tabular}{|c|c|c|c|c|c|c|}
\hline 14 & $\mathrm{H}$ & $\begin{array}{c}\text { 3-(3- } \\
\text { nitrooxypropyloxy) } \\
\text { phenyl (5) }\end{array}$ & $t$-butyl & Phenyl & $\begin{array}{c}\text { pH } 5.5 \text { buffer aqueous } \\
\text { solution, rt, } 24 \mathrm{~h}\end{array}$ & $8 n(25 \%)$ \\
\hline 15 & $\mathrm{CH}_{3}$ & $\begin{array}{c}\text { 3-(4- } \\
\text { nitrooxybutyloxy) } \\
\text { phenyl (6) }\end{array}$ & $t$-butyl & Phenyl & $\begin{array}{l}\mathrm{pH} 5.5 \text { buffer aqueous } \\
\text { solution, rt, } 24 \mathrm{~h}\end{array}$ & $\begin{array}{c}80(23 \%), \\
7 \mathbf{k}(7 \%)\end{array}$ \\
\hline 16 & $\mathrm{H}$ & $\begin{array}{c}\text { 3-(3- } \\
\text { nitrooxypropyloxy) } \\
\text { phenyl (5) }\end{array}$ & $\begin{array}{l}\text { 2-ethyloxy } \\
\text { carbonylethyl }\end{array}$ & Phenyl & Ethanol, rt, $48 \mathrm{~h}$ & $8 p(35 \%)$ \\
\hline 17 & $\mathrm{H}$ & $\begin{array}{c}\text { 3-((3- } \\
\text { (phenylsulfonyl)- } \\
\text { furoxan-4- } \\
\text { yl)oxy)phenyl (4) }\end{array}$ & $t$-butyl & Phenyl & $\underset{\mathrm{min}}{\mathrm{EtOH}, \mathrm{MW}, 60^{\circ} \mathrm{C}, 30}$ & $8 q(25 \%)$ \\
\hline 18 & $\mathrm{H}$ & $\begin{array}{c}\text { 3-((3- } \\
\text { (phenylsulfonyl)- } \\
\text { furoxan-4- } \\
\text { yl)oxy)phenyl (4) }\end{array}$ & Phenetyl & Phenyl & $\begin{array}{c}\mathrm{pH} 5.5 \text { buffer aqueous } \\
\text { solution, rt, } 24 \mathrm{~h}\end{array}$ & $\mathbf{8 r}(8 \%)$ \\
\hline 19 & $\mathrm{H}$ & $\begin{array}{c}\text { 3-((3- } \\
\text { (phenylsulfonyl)- } \\
\text { furoxan-4- } \\
\text { yl)oxy)phenyl (4) }\end{array}$ & $\begin{array}{l}\text { 2-ethyloxy } \\
\text { carbonylethyl }\end{array}$ & Phenyl & $\underset{\min }{\mathrm{EtOH}, \mathrm{MW}, 60{ }^{\circ} \mathrm{C}, 30}$ & $8 s(38 \%)$ \\
\hline
\end{tabular}

Furthermore, the order of addition of the reactants was critical, being the optimal sequence: aldehyde, amine, carboxylic acid and isocyanide under vigorous stirring in the aqueous solution. With the optimum conditions in hand (Table 2, Entry 1), the scope of the reaction was examined next using diverse aldehydes, amines and isocyanides as summarized in Table 2. Under these conditions, when aniline was used in the Ugi reaction, the products 8a-f were obtained in good yields (Table 2, Entries 1-6). However, when using glycine methyl ester in aqueous medium or without solvent under microwave irradiation or at room temperature, the desired product $\mathbf{8 g}$ was isolated in low yield and the Passerini product $\mathbf{7 j}$ was also obtained (Supporting information, Table 1S, Entries 8-10). Fortunately, when the reaction was conducted in ethanol as solvent and microwave as heating source at $60{ }^{\circ} \mathrm{C}$, only the Ugi product $\mathbf{8 g}$ was isolated (Table 2, Entry 7).

A second group of tocopherol-mimetics was synthesized by Ugi reaction under green conditions (Table 2, Entries 8-12). Initially, when 3-(allyloxy)benzaldehyde, aniline, Trolox (2a) and alkylisocyanides were tested in buffer ( $\mathrm{pH} \mathrm{5.5)} \mathrm{at} \mathrm{room} \mathrm{temperature} \mathrm{for} 24$ and $48 \mathrm{~h}$, the bis-amides $\mathbf{8 h}$ and $\mathbf{8 i}$ were obtained in moderate yield (Supporting information, Table 1S, 
Entries 12 and 139). While microwaves have been used in the Ugi reaction and compared with classical procedures, the comparison with the use of ultrasound (US) has not been reported to date. The beneficial effects of the application of ultrasonication in the field of green chemistry have been documented $[37,38]$. In order to reduce the time and improve reaction yields, we tested the effects of ultrasound and compared the results. The Ugi products were in general obtained with improved yields and shorter reaction times, both under solventfree conditions and in aqueous solution, under ultrasound irradiation (Table 2, Entries 9-12).

Further preparation of novel tocopherol-mimetics containing NO-releasing moieties, initially, were performed in $\mathrm{pH} 5.5$ buffer aqueous solution or ethanol as solvent, at room temperature or microwave-assisted (Table 2, entries 13-19). Under these conditions the desired Ugi products 8m-s were isolated in low yield and Passerini product $\mathbf{7 k}$ was also obtained when nitrooxi-aldehyde 6 was used as starting reagent (Table 2, entry 15). These lower yields may be due to the reactivity and stability of the aldehydes 4-6 used (furoxan and nitrooxy derivatives), compared to the above aldehydes used in the Ugi reaction $[39,40]$. Particularly, the ring opening mechanism of the heterocyclic system (furoxan) by nucleophiles such as amines is well-known [41].

Structures of all Passerini and Ugi products were deduced from their mass, ${ }^{1} \mathrm{H}$ NMR, and ${ }^{13} \mathrm{C}$ NMR spectra (see Experimental Section and Supporting Information). We observed that, under the conditions studied, the reactions are not stereoselective and the products are obtained approximately as equimolar mixtures of diastereoisomeric products in all reactions.

\subsection{Antiproliferative activity}

The in vitro antiproliferative activity of the synthesized compounds was measured against six human solid tumor cells, A549 (lung), HBL-100 (breast), HeLa (cervix), SW1573 (lung), T47D (breast) and WiDr (colon), using the sulforhodamine B assay [42, 43]. The results were 
expressed as $\mathrm{GI}_{50}$, which is the drug concentration resulting in a $50 \%$ reduction of cellular net growth when compared with values of untreated control cells. Standard anticancer drugs cisplatin and etoposide were used as positive controls [42, 43]. Results are summarized in Table 3 for the 7a-k Passerini and 8a-s Ugi products.

Overall, the data on antiproliferative activity shows that most of the tested compounds exhibited growth inhibition in all cell lines (Figure 3). In the group of Passerini compounds, the hybrid derivative $\mathbf{7 h}$, which incorporates a sulfonylfuroxan as NO-donor, showed similar $\mathrm{GI}_{50}$ values when compared to the standard anticancer drugs cisplatin and etoposide (Table 3). Particularly, in T-47D (breast) and WiDr (colon) resistant cell lines, this derivative was three to six times more active than the reference drugs. The structure-activity relationship (SAR) study revealed that modifications at $\mathrm{R}^{1}(\mathbf{7} \mathbf{a}-\mathbf{c})$ and $\mathrm{R}^{3}$ (7a and $\left.\mathbf{7 d - f}\right)$ were not a critical factor for modulating the activity, while the incorporation of different NO-donors in $\mathrm{R}^{2}$ (7e and $\mathbf{7 h}$ ) produce a remarkable effect on the antiproliferative activity. Although NO-releasing properties could provide a synergism of action, this might not be the main mechanism of action of these compounds [29, 30]. Moreover, the hybrid compounds $\mathbf{7 k}$ and $\mathbf{7 g}$, which present a morpholine moiety and a methyl ether group in the tocopherol structure, respectively, were inactive in all tumor cell lines tested (Table 3). Similar results were obtained when racemic trolox (2a) (in which the phytyl chain of vitamin $E$ has been replaced by a carboxylic group) was assayed, which highlights the strategy designed to develop tocopherol-mimetics NO-donors via multicomponent reactions. 


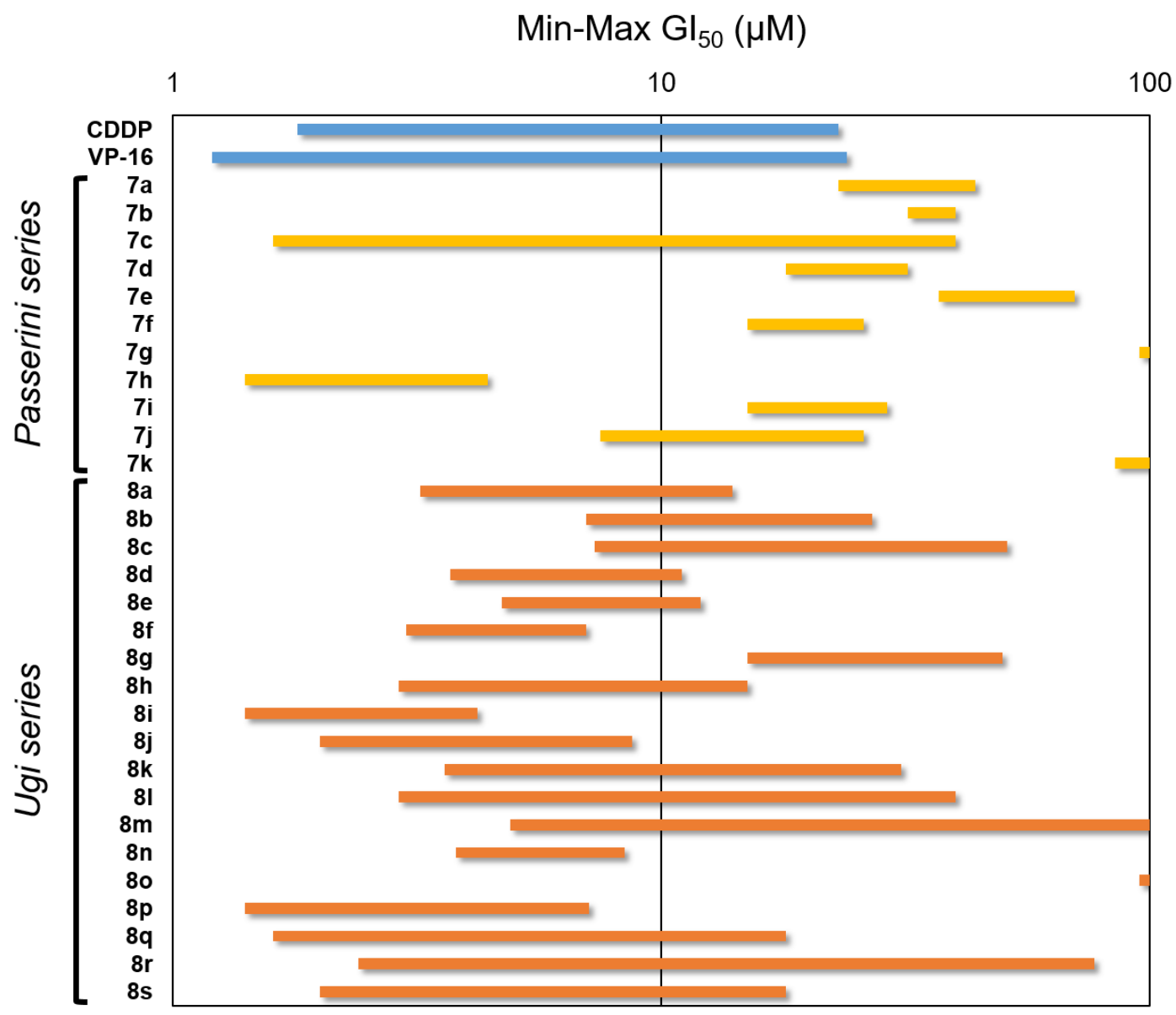

Figure 3. GI50 range plot of tested compounds.

Table 3. Antiproliferative activity $\left(\mathrm{GI}_{50}\right)$ against human solid tumor cells of compounds produced via Passerini reaction and Ugi reaction ${ }^{\mathrm{a}}$

\section{Cell line (type)}

\begin{tabular}{|c|c|c|c|c|c|c|}
\hline Compound & $\begin{array}{l}\text { A549 } \\
\text { (lung) }\end{array}$ & $\begin{array}{c}\text { HBL-100 } \\
\text { (breast) }\end{array}$ & $\begin{array}{c}\text { HeLa } \\
\text { (cervix) }\end{array}$ & $\begin{array}{c}\text { SW1573 } \\
\text { (lung) }\end{array}$ & $\begin{array}{l}\text { T-47D } \\
\text { (breast) }\end{array}$ & $\begin{array}{l}\text { WiDr } \\
\text { (colon) }\end{array}$ \\
\hline $7 \mathbf{a}$ & $25( \pm 1.4)$ & $26( \pm 6.4)$ & $23( \pm 4.2)$ & $29( \pm 4.4)$ & $28( \pm 5.5)$ & $44( \pm 12)$ \\
\hline $7 b$ & $32( \pm 1.7)$ & $40( \pm 9.2)$ & $36( \pm 11)$ & $37( \pm 1.7)$ & $36( \pm 6.6)$ & $32( \pm 17)$ \\
\hline $7 c$ & $4.1( \pm 0.9)$ & $1.6( \pm 0.9)$ & $40( \pm 16)$ & $30( \pm 14)$ & $7.0( \pm 1.4)$ & $4.8( \pm 0.6)$ \\
\hline $7 d$ & $28( \pm 1.6)$ & $24( \pm 0.6)$ & $18( \pm 3.9)$ & $20( \pm 8.4)$ & $32( \pm 3.1)$ & $31( \pm 7.0)$ \\
\hline $7 e$ & $37( \pm 4.9)$ & $44( \pm 7.5)$ & $50( \pm 5.6)$ & $53( \pm 3.5)$ & $70( \pm 42)$ & $58( \pm 44)$ \\
\hline $7 f$ & $25( \pm 3.4)$ & $21( \pm 5)$ & $15( \pm 5.3)$ & $26( \pm 5.5)$ & $24( \pm 0.1)$ & $26( \pm 3.5)$ \\
\hline
\end{tabular}




\begin{tabular}{|c|c|c|c|c|c|c|}
\hline $7 g$ & $>100$ & $>100$ & $>100$ & $>100$ & $>100$ & $>100$ \\
\hline $7 \mathrm{~h}$ & $3.5( \pm 0.3)$ & $2.0( \pm 0.4)$ & $2.5( \pm 0.7)$ & $1.4( \pm 0.1)$ & $4.2( \pm 1.1)$ & $4.4( \pm 1.1)$ \\
\hline $7 \mathbf{i}$ & $18( \pm 7.0)$ & $15( \pm 1.8)$ & $15( \pm 2.4)$ & $18( \pm 7.6)$ & $29( \pm 5.1)$ & $18( \pm 6.5)$ \\
\hline $7 \mathbf{j}$ & $7.5( \pm 1.7)$ & $17( \pm 4.9)$ & $19( \pm 4.9)$ & $16( \pm 4.4)$ & $25( \pm 1.9)$ & $26( \pm 6.1)$ \\
\hline $7 \mathbf{k}$ & $85( \pm 21)$ & $>100$ & $>100$ & $>100$ & $>100$ & $>100$ \\
\hline $8 \mathbf{a}$ & $5.3( \pm 1.3)$ & $4.6( \pm 1.2)$ & $3.2( \pm 1.1)$ & $4.8( \pm 0.1)$ & $4.5( \pm 0.1)$ & $14( \pm 8.0)$ \\
\hline $8 b$ & $7.0( \pm 1.1)$ & $9.2( \pm 6.1)$ & $7.5( \pm 3.7)$ & $7.4( \pm 1.6)$ & $27( \pm 22)$ & $19( \pm 1.2)$ \\
\hline $8 c$ & $7.5( \pm 2.7)$ & $7.3( \pm 1.3)$ & $8.2( \pm 4.6)$ & $8.1( \pm 0.69)$ & $19( \pm 8.9)$ & $51( \pm 4.6)$ \\
\hline 8d & $4.7( \pm 0.9)$ & $5.6( \pm 1.3)$ & $4.1( \pm 1.0)$ & $3.7( \pm 1.6)$ & $5.6( \pm 0.5)$ & $11( \pm 6.8)$ \\
\hline $8 e$ & $7.1( \pm 4.9)$ & $5.0( \pm 0.8)$ & $4.7( \pm 2.7)$ & $5.1( \pm 0.1)$ & $12( \pm 8.8)$ & $11( \pm 5.8)$ \\
\hline $8 f$ & $7.0( \pm 5.1)$ & $5.0( \pm 0.9)$ & $3.0( \pm 0.8)$ & $5.2( \pm 0.7)$ & $5.4( \pm 0.7)$ & $6.2( \pm 2.8)$ \\
\hline $8 g$ & $15( \pm 5.3)$ & $24( \pm 2.9)$ & $19( \pm 3.8)$ & $18( \pm 5.1)$ & $36( \pm 5.6)$ & $50( \pm 6.5)$ \\
\hline $8 \mathrm{~h}$ & $2.9( \pm 1.1)$ & $5.1( \pm 1.1)$ & $5.2( \pm 0.5)$ & $3.0( \pm 0.3)$ & $6.9( \pm 1.5)$ & $15( \pm 6.8)$ \\
\hline $8 \mathbf{i}$ & $1.4( \pm 0.5)$ & $4.2( \pm 0.1)$ & $2.8( \pm 0.6)$ & $3.3( \pm 0.5)$ & $3.5( \pm 0.9)$ & $3.8( \pm 1.3)$ \\
\hline $8 \mathbf{j}$ & $2.0( \pm 0.6)$ & $2.5( \pm 1.3)$ & $2.3( \pm 0.7)$ & $7.8( \pm 1.5)$ & $6.4( \pm 0.5)$ & $8.7( \pm 0.1)$ \\
\hline $8 \mathbf{k}$ & $3.6( \pm 1.6)$ & $4.5( \pm 1.5)$ & $4.7( \pm 1.0)$ & $4.0( \pm 0.2)$ & $12( \pm 0.8)$ & $31( \pm 1.0)$ \\
\hline 81 & $4.9( \pm 0.9)$ & $6.4( \pm 0.1)$ & $6.4( \pm 1.7)$ & $2.9( \pm 0.7)$ & $20( \pm 8.5)$ & $40( \pm 17)$ \\
\hline $8 m$ & $4.9( \pm 2.9)$ & $10( \pm 0.8)$ & $75( \pm 35)$ & $78( \pm 31)$ & $>100$ & $>100$ \\
\hline $8 n$ & $3.8( \pm 1.6)$ & $6.0( \pm 1.2)$ & $4.1( \pm 0.7)$ & $8.4( \pm 2.2)$ & $4.6( \pm 0.4)$ & $6.7( \pm 5.3)$ \\
\hline 80 & $>100$ & $>100$ & $>100$ & $>100$ & $>100$ & $>100$ \\
\hline $8 p$ & $3.4( \pm 0.8)$ & $1.4( \pm 0.1)$ & $4.2( \pm 1.8)$ & $3.4( \pm 0.6)$ & $5.2( \pm 1.9)$ & $7.1( \pm 3.4)$ \\
\hline $8 q$ & $5.4( \pm 2.3)$ & $1.9( \pm 0.5)$ & $1.9( \pm 0.7)$ & $1.6( \pm 0.4)$ & $5.3( \pm 2.6)$ & $18( \pm 4.0)$ \\
\hline $8 r$ & $21( \pm 5.6)$ & $2.4( \pm 0.5)$ & $14( \pm 4.9)$ & $4.1( \pm 1.2)$ & $22( \pm 7.3)$ & $77( \pm 16)$ \\
\hline $8 s$ & $14( \pm 5.5)$ & $2.2( \pm 0.6)$ & $3.6( \pm 0.5)$ & $2.0( \pm 0.3)$ & $14( \pm 2.4)$ & $18( \pm 5.8)$ \\
\hline Trolox (2a) & $>100$ & $>100$ & $>100$ & $>100$ & $>100$ & $>100$ \\
\hline \multicolumn{7}{|l|}{ Cisplatin } \\
\hline (CDDP) & $2.1( \pm 0.6)$ & $1.9( \pm 0.3)$ & $2.0( \pm 0.3)$ & $3.0( \pm 0.4)$ & $15( \pm 2.3)$ & $26( \pm 5.3)$ \\
\hline \multicolumn{7}{|l|}{ Etoposide } \\
\hline (VP-16) & $1.5( \pm 0.2)$ & $2.3( \pm 0.9)$ & $3.0( \pm 0.9)$ & $15( \pm 1.5)$ & $22( \pm 5.5)$ & $23( \pm 3.1)$ \\
\hline
\end{tabular}

\footnotetext{
${ }^{\text {a }}$ Values are given in $\mu \mathrm{M}$ and are means of two to three experiments; standard deviation is given in parentheses.
} 
The Ugi derivatives, both tocopherol-mimetic as tocopherol-mimetic NO-donors hybrid compounds, were in general more active than the Passerini derivatives (Figure 3). The most active Ugi compounds were $\mathbf{8 f}, \mathbf{8 i}, \mathbf{8 j}, \mathbf{8 n}$ and $\mathbf{8 p}$, exhibiting $\mathrm{GI}_{50}$ values against all cells in the range 1.4-8.7 $\mu \mathrm{M}$ (Table 3). When compared to cisplatin and etoposide, these compounds showed an improved biological activity in the more resistant cell lines T-47D and WiDr.

From this series, compound $\mathbf{8 i}$ was the most active against all tumor cells, with $\mathrm{GI}_{50}$ values four to seven times more active than the reference drugs in the resistant cell lines T-47D and WiDr. In the latter compound, the incorporation of an allyloxy substituent compared to its analogue $\mathbf{8 b}$, enhanced the antiproliferative activity in all tumor cell lines. Besides, it should be noted that incorporation of NO-donors, both furoxan as nitrooxy moiety, did not exhibit dramatic additive effect in the antiproliferative activities of Ugi compounds (8a-l vs $\mathbf{8 m}-\mathbf{s}$ ). The remaining active derivatives showed moderate activity with $\mathrm{GI}_{50}$ values in the range 10$78 \mu \mathrm{M}$, with exception of compound 8a. Similar to Passerini compound $\mathbf{7 k}$, the presence of a methyl ether group in the tocopherol structure of the Ugi compound 8o, proved inactive in all tumor lines evaluated (Table 3).

\subsection{Selectivity index.}

To determine the specificity of cytotoxic activity against cancer cell lines, it was necessary to obtain information of cytotoxicity against normal cells. Therefore, unspecific mammalian cytotoxicity of selected compounds $(\mathbf{7 a}, \mathbf{7} \mathbf{c}, \mathbf{7 h}, \mathbf{8 i}, \mathbf{8 n}, \mathbf{8 p}, \mathbf{8 q})$ were evaluated in vitro at 1$100 \mu \mathrm{M}$, using human macrophage-like cells (phorbol ester differentiated THP-1 cells) [17]. The cytotoxicity for macrophages and antiproliferative activity for each tumor cell lines was compared using the selectivity index (SI), which was determined as the ratio between $\mathrm{EC}_{50}$ for macrophages and $\mathrm{GI}_{50}$ for each tumor cell lines. SI values are summarized in Table 4. All compounds present SI values of at least twice the corresponding $\mathrm{GI}_{50}$ values. Taking into 
account that we are interested in the maximum activity with minimal cell toxicity, our results showed that $\mathbf{8 i}$ is the compound with the best profile and may be considered as a future candidate for the development of potent chemotherapeutic agents.

Table 4. Cytotoxicity of Passerini-3C and Ugi-4C derivatives against THP-1 human macrophages and selectivity index.

\begin{tabular}{cccccccc}
\hline \multirow{2}{*}{ Compound } & $\begin{array}{c}\text { THP-1 } \\
\text { cytotoxicity } \\
\mathbf{E C}_{\mathbf{5 0}}(\boldsymbol{\mu} \mathbf{M})^{\mathbf{a}}\end{array}$ & $\mathbf{A 5 4 9}$ & HBL-100 & HeLa & SW1573 & T-47D & WiDr \\
\hline $\mathbf{7 a}$ & 79 & 3.2 & 3.0 & 3.4 & 2.7 & 2.8 & 1.8 \\
\hline $\mathbf{7 c}$ & 90 & 22 & 56 & 2.3 & 3.0 & 13 & 19 \\
\hline $\mathbf{7 h}$ & 10 & 2.9 & 5.0 & 4.0 & 7.1 & 2.4 & 2.4 \\
\hline $\mathbf{8 i}$ & $>100$ & $>71$ & $>24$ & $>36$ & $>30$ & $>29$ & $>26$ \\
\hline $\mathbf{8 n}$ & 67 & 17 & 11 & 16 & 8.0 & 15 & 10 \\
\hline $\mathbf{8 p}$ & 37 & 11 & 26 & 8.8 & 11 & 7.1 & 7.3 \\
\hline $\mathbf{8 q}$ & 59 & 11 & 31 & 31 & 37 & 11 & 3.3 \\
\hline
\end{tabular}

${ }^{a}$ The results are the means of four independent experiments with a SD less than $10 \%$ in all cases. ${ }^{b}$ SI: selectivity index, $\mathrm{EC}_{50}$, macrophage / GI50,tumor cell (line).

\subsection{Apoptosis}

Programmed cell death is characterized by modifications of the plasma membrane and translocation of the phosphatidyl serine (PS) to the outer plasma membrane leaflet is one of the first events observed in apoptosis. Annexin V-FITC is a fluorescent probe with high affinity for PS allowing its determination by fluorescence assays. Figures 4 and 5 display the capacity of compounds $\mathbf{7 h}, \mathbf{8 i}, \mathbf{8 n}$ and $\mathbf{8 q}$ to induce apoptosis on THP-1 and T-47D cells after 24 h of treatment evaluated by flow cytometry. In THP-1 cells, only compounds $7 \mathbf{h}$ and $\mathbf{8 q}$ were able to increase apoptotic cells as determined by Annexin V staining (2 and 6 fold change compare to control, respectively, Figure 4). On the other hand, when T-47D cells were exposed to compounds $\mathbf{7 h}, \mathbf{8 i}, \mathbf{8 n}$ and $\mathbf{8 q}$ the percentage of AnnexinV positive cells were 
increased from to 2 to 5 times respect to the control (Figure 5). Taking into account these results and the SI, compound $\mathbf{8 i}$ was selected for further characterization.

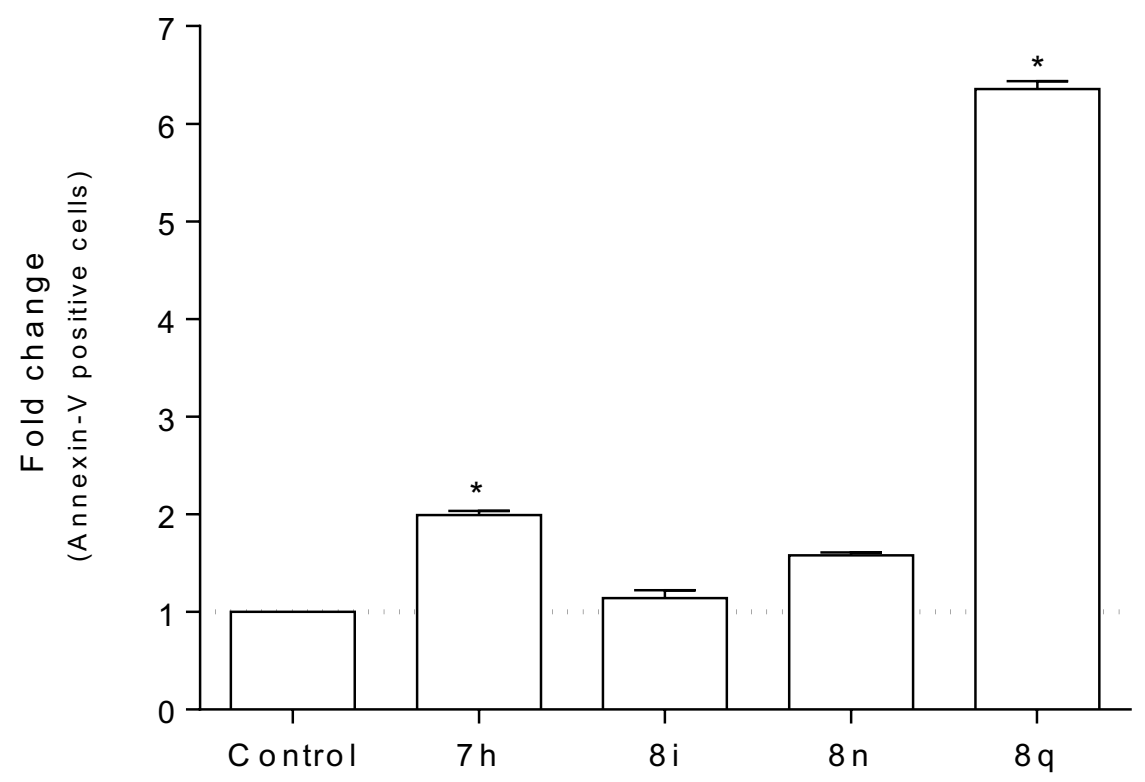

Figure 4. Apoptosis assessment using Annexin V staining. THP-1 cells were treated with compounds $\mathbf{7 h}, \mathbf{8 i}, \mathbf{8 n}$ and $\mathbf{8 q}(4.2 ; 3.5 ; 4.6 ; 5.3 \mu \mathrm{M}$, respectively). The percentage of Annexin $\mathrm{V}$ positive cells was determined by flow cytometry. Results were normalized against vehicle control (DMSO). Graph is one representative out of three independent experiments. * Significant differences vs. DMSO control $(\mathrm{p}<0.01)$.

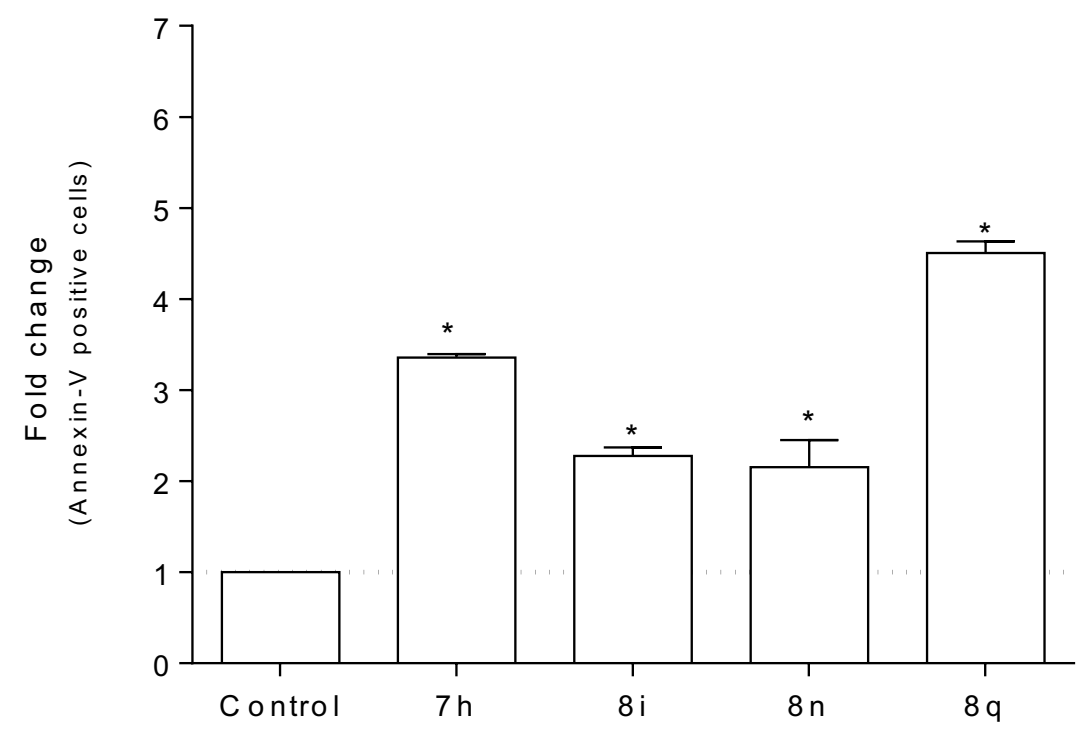


Figure 5. Apoptosis assessment using Annexin V staining. T-47D cells were treated with compounds $7 \mathbf{h}, \mathbf{8 i}, \mathbf{8 n}$ and $\mathbf{8 q}(4.2 ; 3.5 ; 4.6 ; 5.3 \mu \mathrm{M}$, respectively). The percentage of Annexin V positive cells was determined by flow cytometry. Results were normalized against vehicle control (DMSO). Graph is one representative out of three independent experiments. * Significant differences vs. DMSO control $(\mathrm{p}<0.01)$.

\subsection{Cell cycle analysis.}

Since compound $\mathbf{8 i}$ showed selective toxicity and was able to induce apoptosis in tumor cells but not in normal cells, we further investigate its effect on the cell cycle phases distribution. The exposure of T-47D cells to compound $8 \mathbf{i}(3.5 \mu \mathrm{M})$ for $48 \mathrm{~h}$ produced an accumulation of cells in $\mathrm{G}_{0} / \mathrm{G}_{1}$ phase (Figure 6), which was concomitant with a decrease in $\mathrm{S}$ and $\mathrm{G}_{2} / \mathrm{M}$ phases. It should be noted that under these experimental conditions no sub-G peak was detected.

Control

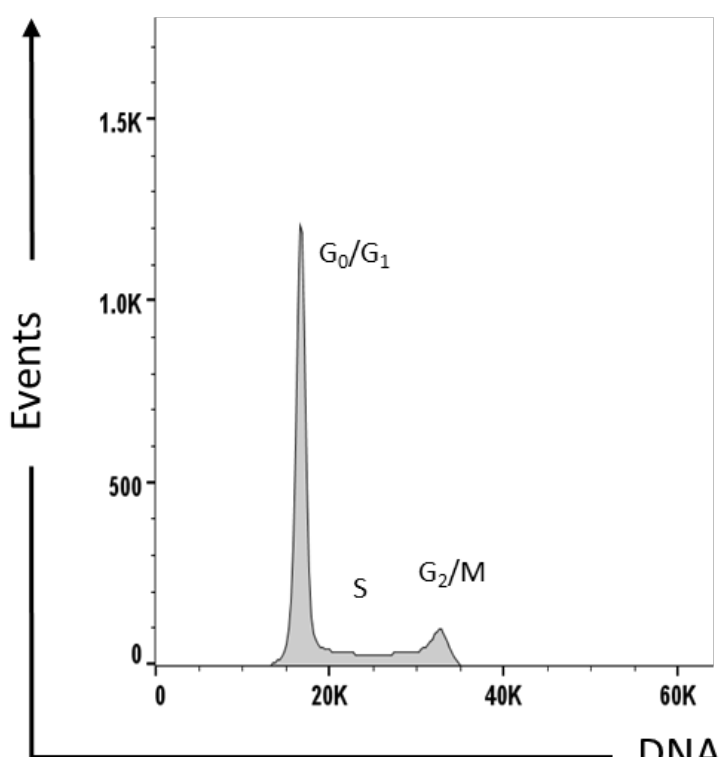

$8 \mathbf{i}$

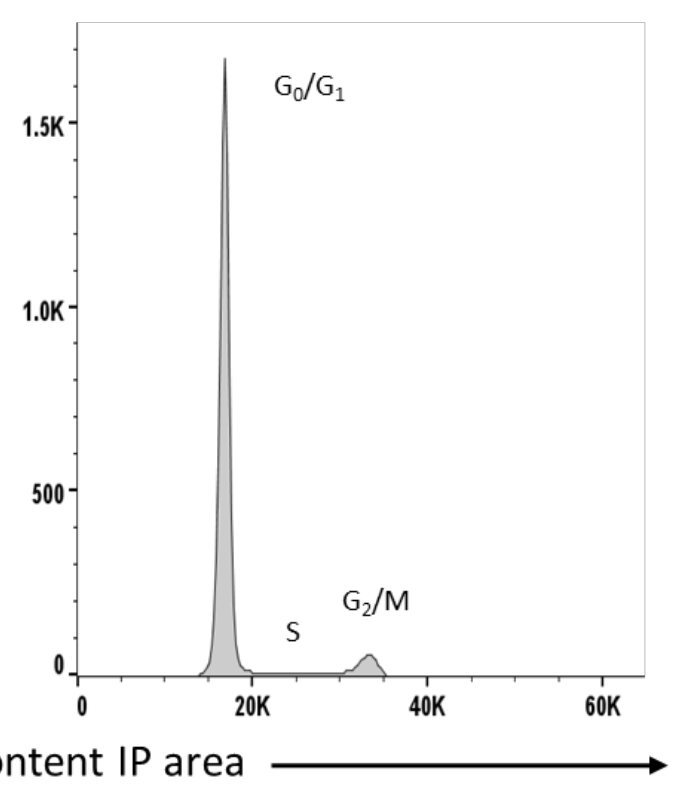




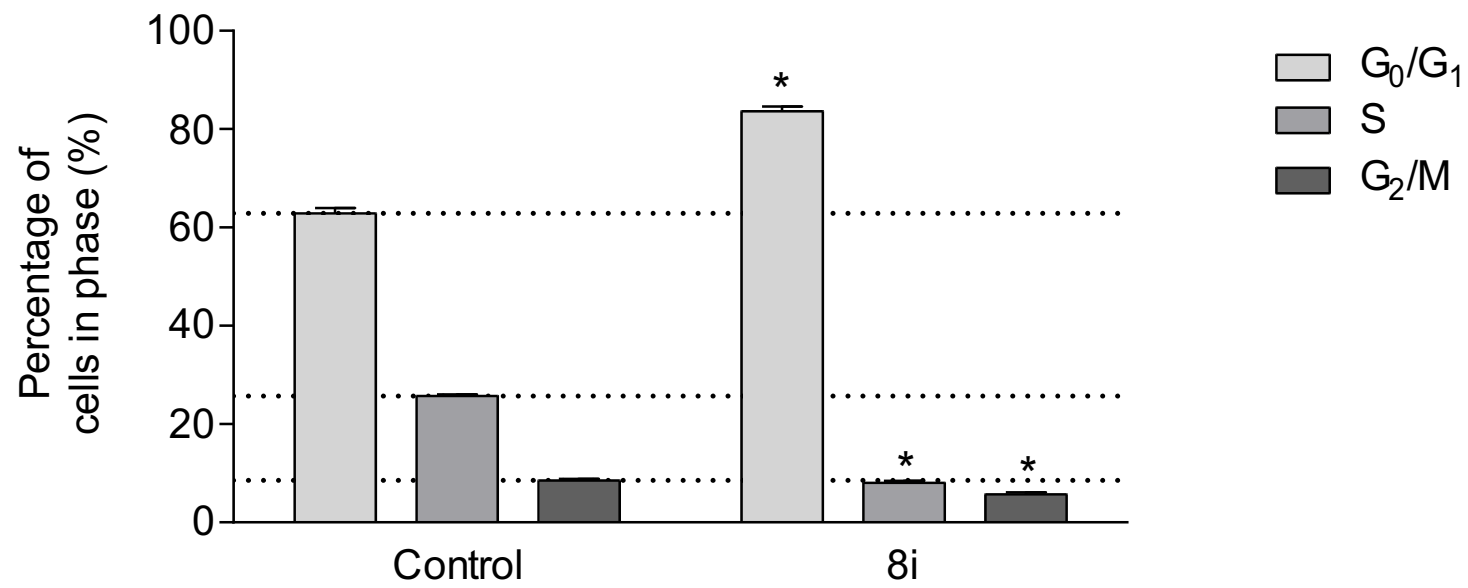

Figure 6. Effect of $\mathbf{8 i}$ compound on cell cycle arrest assessed by flow cytometry and PI stain. T-47D cells were treated with $8 \mathbf{i}(3.5 \mu \mathrm{M})$ for 48 h. DMSO was used as vehicle control. Upper figure: representative example of DNA content frequency histograms corresponding to control and treated cells. Lower figure: bars show the percentage of cells in each cell cycle phase. Results are expressed as the mean $\pm \mathrm{SEM}, \mathrm{n}=3$. * Significant differences vs. control $(\mathrm{p}<0.01)$.

\section{Conclusions}

Passerini 3-CR and Ugi 4-CR coupling reactions were used to assemble tocopherol-mimetic and tocopherol-mimetic NO-donors hybrid compounds from simple starting materials in a single synthetic step under eco-friendly conditions. The synthesis of these tocopherol analogues was achieved using microwave irradiation or ultrasound as the energy source. The main advantages of the present procedure are: i) cleaner reactions with improved yields, ii) milder conditions, iii) shorter reaction times and iv) experimental simplicity. The obtained library of tocopherol analogues was tested against six human solid tumor cell lines showing most of them the ability to inhibit cell growth, with $\mathrm{GI}_{50}$ values in the range $1-78 \mu \mathrm{M}$. The Passerini derivative $\mathbf{7 h}$ and Ugi derivatives $8 \mathbf{f}, \mathbf{8 i}, \mathbf{8 j}, \mathbf{8 n}$ and $\mathbf{8 p}$, showed high levels of antiproliferative activity, exhibiting $\mathrm{GI}_{50}$ values against all cells in the range 1.4-8.7 $\mu \mathrm{M}$. 
Particularly, in T-47D (breast) and WiDr (colon) resistant cell lines, tocopherol analogues $\mathbf{7 h}$ and $\mathbf{8 i}$ were three to seven times more active than cisplatin and etoposide, the two used reference drugs. In addition, $\mathbf{7 h}$ compound was able to induce apoptosis in T-47D and THP-1 cells, while 8i was more selective since only affect T-47D and not normal cells (THP-1). Furthermore, the analogue $\mathbf{8 i}$ produced a cell cycle arrest in T-47D cells. Altogether, considering that we are interested in the maximum activity with minimal cell toxicity, $\mathbf{8 i}$ is the compound with best performance and may be considered as a future candidate for the development of potent tocopherol-mimetic therapeutic agents for cancer. Future studies should get a deeper inside in its antiproliferative mechanism as well as in vivo experiments.

\section{Materials and methods}

\subsection{Materials}

All starting materials were commercially available research grade chemicals and used without further purification. RPMI 1640 medium was purchased from Flow Laboratories (Irvine, UK), fetal calf serum (FCS), Fetal Bovine Serume (FBS) and GlutaMAX were from Gibco (Grand Island, NY), trichloroacetic acid (TCA) and glutamine were from Merck (Darmstadt, Germany), and $\beta$-mercaptoethanol, phorbol 12-myristate 13-acetate (PMA), penicillin G, streptomycin, DMSO, sulforhodamine B (SRB) and 3-[4,5-dimethylthiazol-2yl]-2,5diphenyltetrazolium bromide (MTT) were from Sigma (St Louis, MO).

All solvents were distilled prior to use. Analytical TLC was performed on silica gel 60F-254 plates and visualized with UV light $(254 \mathrm{~nm})$ and/or p-anisaldehyde in acidic ethanolic solution. Column chromatography was performed using silica gel (SAI, 63-200 $\mu \mathrm{m}$ ). Microwave-assisted reactions were conducted in sealed glass vessels (capacity $10 \mathrm{~mL}$ ) using a CEM Discover microwave reactor. Ultrasound-assisted reactions were carried out in roundbottom flasks using an ultrasonic bath (Ultrasons-H, J.P. Selecta). Proton and carbon NMR 
spectra were recorded on a Bruker DPX-400 spectrometer. The chemical shifts values are expressed in ppm relative to tetramethylsilane as internal standard and coupling constants and are expressed in Hertz, followed by multiplicity indicated as s: singlet, d: doublet, t: triplet, q: quartet or combination, bs broad singlet or m: multiplet. Mass spectra were determined on a Shimadzu DI-2010. High-resolution mass spectra were recorded with a Micromass Autospec mass spectrometer. Melting points were determined by open glass capillary method on a melting point apparatus Electrothermal 9100.

All other materials were obtained from commercial suppliers and used as received.

\subsection{Experimental procedures}

Methyl 6-benzyloxy-2,5,7,8-tetramethylchroman-2-carboxylate (1b): methyl 6-hydroxy2,5,7,8-tetramethylchroman-2-carboxylate $1 \mathrm{a}(9.5 \mathrm{mmol}, 2.5 \mathrm{~g})$ was dissolved in dry DMF (15 mL). Benzyl bromide (0.014 mol, $2.2 \mathrm{~mL})$ and $\mathrm{K}_{2} \mathrm{CO}_{3}(0.019 \mathrm{~mol}, 2.6 \mathrm{~g})$ were added and the reaction was heated at $110{ }^{\circ} \mathrm{C}$ for $12 \mathrm{~h}$. The reaction mixture was washed with a $10 \%$ aqueous solution of $\mathrm{HCl}(50 \mathrm{~mL})$ and extracted with $\mathrm{Et}_{2} \mathrm{O}(7 \times 10 \mathrm{~mL})$. The combined organic layers were washed with water $(50 \mathrm{~mL})$ and brine $(50 \mathrm{~mL})$, and then dried over $\mathrm{Na}_{2} \mathrm{SO}_{4}$, filtered and the solvent was evaporated under reduced pressure. Purification by column chromatography in $\mathrm{SiO}_{2}$ and hexane:EtOAc 9:1 as mobile phase, rendered the desired product as a colorless solid $(2.9 \mathrm{~g}, 88 \%) .{ }^{1} \mathrm{H} \mathrm{NMR}\left(\mathrm{CDCl}_{3}, 400 \mathrm{MHz}\right): \delta 7.45-7.29(\mathrm{~m}, 5 \mathrm{H}), 4.67$ (s, 2H), $3.64(\mathrm{~s}, 3 \mathrm{H}), 2.37-2.62(\mathrm{~m}, 1 \mathrm{H}), 2.45(\mathrm{~m}, 2 \mathrm{H}), 2.18(\mathrm{~s}, 3 \mathrm{H}), 2.14(\mathrm{~s}, 3 \mathrm{H}), 2.08(\mathrm{~s}, 3 \mathrm{H})$, $1.80-1.86(\mathrm{~m}, 1 \mathrm{H}), 1.57(\mathrm{~s}, 3 \mathrm{H})$.

Methyl 6-methoxy-2,5,7,8-tetramethylchroman-2-carboxylate (1c): methyl 6-hydroxy2,5,7,8-tetramethylchroman-2-carboxylate $1 \mathrm{a}(3.8 \mathrm{mmol}, 1.00 \mathrm{~g})$, dimethyl carbonate $(0.125$ mol, $10.5 \mathrm{~mL}), \mathrm{DBU}(3.8 \mathrm{mmol}, 0.6 \mathrm{~mL})$ and TBAI $(3.8 \mathrm{mmol}, 1.40 \mathrm{~g})$ were added into a microwave reactor and heated for $90 \mathrm{~min}$ at $90^{\circ} \mathrm{C}(300 \mathrm{~W})$. Then, the reaction mixture was 
washed with a $10 \%$ aqueous solution of $\mathrm{NaOH}(50 \mathrm{~mL}), 10 \%$ aqueous solution of $\mathrm{HCl}(50$ $\mathrm{mL})$ and water $(50 \mathrm{~mL})$, and extracted with EtOAc. The organic layers were dried with $\mathrm{Na}_{2} \mathrm{SO}_{4}$, filtered and the solvent was evaporated under reduced pressure. Purification by column chromatography in $\mathrm{SiO}_{2}$ and hexane: ethyl acetate 8:2 as mobile phase rendered the desired product as a white solid $(0.64 \mathrm{~g}, 60 \%) .{ }^{1} \mathrm{H} \mathrm{NMR}\left(\mathrm{CDCl}_{3}, 400 \mathrm{MHz}\right): \delta 3.70(\mathrm{~s}, 3 \mathrm{H})$, $3.64(\mathrm{~s}, 3 \mathrm{H}), 2.68(\mathrm{~m}, 1 \mathrm{H}), 2.52(\mathrm{~m}, 2 \mathrm{H}), 2.21(\mathrm{~s}, 3 \mathrm{H}), 2.18(\mathrm{~s}, 3 \mathrm{H}), 2.12(\mathrm{~s}, 3 \mathrm{H}), 1.96(\mathrm{~m}$, 1H), $1.63(\mathrm{~s}, 3 \mathrm{H})$.

Methyl 6-((tert-butoxycarbonyl)oxy)-2,5,7,8-tetramethylchroman-2-carboxylate (1d): To a solution of $1 \mathbf{a}(2.30 \mathrm{~g}, 8.5 \mathrm{mmol})$ in THF $(20 \mathrm{~mL})$ were added di-tert-butyldicarbonate $(2.00$ g, $8.5 \mathrm{mmol})$ and 4,4-dimethylaminopyridine $(0.10 \mathrm{~g}, 0.9 \mathrm{mmol})$ under nitrogen atmosphere. The solution was stirred at room temperature for $6 \mathrm{~h}$ and the solvent was evaporated. The residue was dissolved in EtOAc $(50 \mathrm{~mL})$, washed with $0.5 \mathrm{~N}$ aqueous solution of $\mathrm{HCl}$ (30 $\mathrm{mL})$, and brine $(20 \mathrm{~mL})$. The organic layer was dried $\left(\mathrm{MgSO}_{4}\right)$ and the solvent evaporated. The crude product was purified by column chromatography (Hexane/EtOAc, 90:10) to give the titled compound $(2.4 \mathrm{~g}, 75 \%$ yield $)$ as a colorless oil which crystallized on cooling. ${ }^{1} \mathrm{H}$ NMR $\left(\mathrm{CDCl}_{3}, 400 \mathrm{MHz}\right): \delta 3.70(\mathrm{~s}, 3 \mathrm{H}), 2.69(\mathrm{~m}, 1 \mathrm{H}), 2.53(\mathrm{~m}, 1 \mathrm{H}), 2.45(\mathrm{~m}, 1 \mathrm{H}), 2.18(\mathrm{~s}$, $3 \mathrm{H}), 2.11(\mathrm{~s}, 3 \mathrm{H}), 2.02(\mathrm{~s}, 3 \mathrm{H}), 1.88(\mathrm{~m}, 1 \mathrm{H}), 1.62(\mathrm{~s}, 3 \mathrm{H}), 1.57$ (s, 9H).

6-Benzyloxy-2,5,7,8-tetramethylchroman-2-carboxylic acid (2c): Compound $\mathbf{1 b}(1 \mathrm{mmol}$, $0.30 \mathrm{~g})$ was dissolved in ethanol/water 2.5:1 and $\mathrm{LiOH} \mathrm{H}_{2} \mathrm{O}(3.5 \mathrm{mmol}, 0.15 \mathrm{~g})$ was added. Reaction was stirred at room temperature for $48 \mathrm{~h}$ and then water was added $(30 \mathrm{~mL})$. The reactant solution was extracted with EtOAc $(4 \times 10 \mathrm{~mL})$ and then washed with a $10 \% \mathrm{HCl}$ solution until pH 3. The resulting organic layers were dried with $\mathrm{Na}_{2} \mathrm{SO}_{4}$, filtered and the solvent was evaporated under reduced pressure, to give a white solid $(0.22 \mathrm{~g}, 85 \%)$ without any further purification. ${ }^{1} \mathrm{H} \mathrm{NMR}\left(\mathrm{CDCl}_{3}, 400 \mathrm{MHz}\right): \delta 7.52-7.37(\mathrm{~m}, 5 \mathrm{H}), 4.71(\mathrm{~s}, 2 \mathrm{H}), 2.74-$ 
$2.60(\mathrm{~m}, 2 \mathrm{H}), 2.45-2.38(\mathrm{~m}, 1 \mathrm{H}), 2.25(\mathrm{~s}, 3 \mathrm{H}), 2.19(\mathrm{~s}, 3 \mathrm{H}), 2.17(\mathrm{~s}, 3 \mathrm{H}), 2.02-1.94(\mathrm{~m}, 1 \mathrm{H})$, $1.66(\mathrm{~s}, 3 \mathrm{H})$.

6-Methyloxy-2,5,7,8-tetramethylchroman-2-carboxylic acid (2d): Compound 1c (2.8 mmol, $1.00 \mathrm{~g})$ was dissolved in ethanol/water 2.5:1 and $\mathrm{LiOH} . \mathrm{H}_{2} \mathrm{O}(0.011 \mathrm{~mol}, 0.50 \mathrm{~g})$ was added. Reaction was stirred at room temperature for $24 \mathrm{~h}$ and then water was added $(50 \mathrm{~mL})$. The solution was extracted with EtOAc $(3 \times 10 \mathrm{~mL})$ and then washed with a $10 \% \mathrm{HCl}$ solution until $\mathrm{pH}$ 3. The resulting organic layers were dried with $\mathrm{Na}_{2} \mathrm{SO}_{4}$, filtered and the solvent was evaporated under reduced pressure, to give a yellowish solid (0.93 g, 97\%) without any further purification. ${ }^{1} \mathrm{H}$ NMR $\left(\mathrm{CDCl}_{3}, 400 \mathrm{MHz}\right): \delta 3.62(\mathrm{~s}, 3 \mathrm{H}), 2.69-2.53(\mathrm{~m}$, 2H), 2.41-2.35 (m, 1H), $2.19(\mathrm{~s}, 3 \mathrm{H}), 2.14(\mathrm{~s}, 3 \mathrm{H}), 2.11(\mathrm{~s}, 3 \mathrm{H}), 1.96-1.88(\mathrm{~m}, 1 \mathrm{H}), 1.62(\mathrm{~s}$, $3 \mathrm{H})$.

6-((tert-Butoxycarbonyl)oxy)-2,5,7,8-tetramethylchroman-2-carboxylic acid (2e):

Compound 1d (1.4 mmol, $0.50 \mathrm{~g}$ ) was dissolved in ethanol/water 2.5:1 and $\mathrm{LiOH} . \mathrm{H}_{2} \mathrm{O}(5.2$ mmol, $0.22 \mathrm{~g}$ ) was added. Reaction was stirred at room temperature for $24 \mathrm{~h}$ and then $\mathrm{NH}_{4} \mathrm{Cl}$ saturated aqueous solution was added $(30 \mathrm{~mL})$. The aqueous solution was extracted with EtOAc $(4 \times 10 \mathrm{~mL})$. The resulting organic layers were dried with $\mathrm{Na}_{2} \mathrm{SO}_{4}$, filtered and the solvent was evaporated under reduced pressure, to give a white solid $(0.48 \mathrm{~g}, 100 \%)$ without any further purification. ${ }^{1} \mathrm{H} \mathrm{NMR}\left(\mathrm{CDCl}_{3}, 400 \mathrm{MHz}\right): \delta 2.64(\mathrm{~m}, 2 \mathrm{H}), 2.36(\mathrm{~m}, 1 \mathrm{H}), 2.18(\mathrm{~s}$, 3H), $2.10(\mathrm{~s}, 3 \mathrm{H}), 2.02(\mathrm{~s}, 3 \mathrm{H}), 1.73(\mathrm{~m}, 1 \mathrm{H}), 1.62(\mathrm{~s}, 3 \mathrm{H}), 1.57(\mathrm{~s}, 9 \mathrm{H}) .{ }^{13} \mathrm{C} \mathrm{NMR}\left(\mathrm{CDCl}_{3}\right.$, $100 \mathrm{MHz}): \delta 173.6,152.2,149.2,141.5,127.1,125.1,122.9,117.1,82.7,77.2,34.7,30.2$, 27.6, 20.8, 12.7, 12.5, 11.8. MS (EI, $70 \mathrm{eV}): m / z(\%) 350\left(\mathrm{M}^{+}, 5\right), 291(10), 250(100), 205$ (24), 164 (38), 57 (76). HRMS $m / z$ calcd for $\mathrm{C}_{19} \mathrm{H}_{26} \mathrm{O}_{6}[\mathrm{M}+\mathrm{H}]^{+} 350.1729$, found 350.1735.

General procedure for Passerini products $(7 \mathbf{a}, 7 \mathbf{7 b}, \mathbf{7 d - h})$. A glass tube was charged sequentially with chromancarboxylic acid (1 eq), furoxan aldehyde (1 eq), and isocyanide (1 
eq). The sealed test tube was heated $15 \mathrm{~min}$ at $60{ }^{\circ} \mathrm{C}$ by microwave irradiation. The vial was allowed to cool, and the crude reaction mixture was treated with aqueous-saturated $\mathrm{NaHCO}_{3}$ solution and extracted with EtOAc. The organic layer was washed with brine, dried with $\mathrm{Na}_{2} \mathrm{SO}_{4}$ and evaporated under reduced pressure. The residue was purified by flash column chromatography $\left(\mathrm{SiO}_{2}, \mathrm{Hexane} /\right.$ EtOAc) .

\section{1-(3-methyl-1,2,5-oxadiazol-4-yl $\quad N^{2}$-oxide)-1-(phenethylaminocarbonyl)methyl 6-} hydroxy-2,5,7,8-tetramethylchroman-2-carboxylate (7a). Compound 7a was prepared according to a previously reported method [27]. ${ }^{1} \mathrm{H} \mathrm{NMR}\left(\mathrm{CDCl}_{3}, 400 \mathrm{MHz}\right): \delta 7.33-7.22(\mathrm{~m}$, 6H), 7.15-7.12 (m, 4H), $6.09(\mathrm{~s}, 1 \mathrm{H}), 6.08(\mathrm{t}, J=5.9 \mathrm{~Hz}, 1 \mathrm{H}), 5.92(\mathrm{~s}, 1 \mathrm{H}), 5.53(\mathrm{t}, J=5.9 \mathrm{~Hz}$, $1 \mathrm{H}), 4.51(\mathrm{~s}, 1 \mathrm{H}), 4.40(\mathrm{~s}, 1 \mathrm{H}), 3.59-3.50(\mathrm{~m}, 1 \mathrm{H}), 3.47-3.39(\mathrm{~m}, 1 \mathrm{H}), 3.26-3.17(\mathrm{~m}, 1 \mathrm{H})$, 3.11-3.02 (m, 1H), 2.76-2.36 (m, 12H), $2.23(\mathrm{~s}, 3 \mathrm{H}), 2.21(\mathrm{~s}, 3 \mathrm{H}), 2.18(\mathrm{~s}, 3 \mathrm{H}), 2.12(\mathrm{~s}, 3 \mathrm{H})$, 2.11(s, 3H), $2.10(\mathrm{~s}, 3 \mathrm{H}), 2.06(\mathrm{~s}, 3 \mathrm{H}), 1.93(\mathrm{~s}, 3 \mathrm{H}), 1.99-1.88(\mathrm{~m}, 2 \mathrm{H}), 1.67(\mathrm{~s}, 3 \mathrm{H}), 1.64(\mathrm{~s}$, 3H). ${ }^{13} \mathrm{C} \mathrm{NMR}\left(\mathrm{CDCl}_{3}, 100 \mathrm{MHz}\right): \delta 172.35,164.16,153.47,145.97,145.45,137.87,128.70$, $126.81,122.50,121.91,119.43,117.20,112.16,77.61,66.75,40.0,35.41,30.75,25.36$, 20.73, 12.47, 11.83, 11.42, 7.93. MS (EI, $70 \mathrm{eV}): m / z(\%) 509\left(\mathrm{M}^{+}, 100\right), 452(35), 250(19)$, 205 (73), 203 (93), 189(20), 164 (25), 105 (25), 91 (18), 69 (25). HRMS m/z calcd for $\mathrm{C}_{27} \mathrm{H}_{31} \mathrm{~N}_{3} \mathrm{O}_{7}[\mathrm{M}+\mathrm{Na}]^{+}$532.2054, found 532.2092.

\section{1-(3-methyl-1,2,5-oxadiazol-4-yl- $\mathrm{N}^{2}$-oxide)-1-(phenethylaminocarbonyl)methyl} acetyloxy-2,5,7,8-tetramethylchroman-2-carboxylate (7b). Compound $7 \mathbf{b}$ was prepared according to a previously reported method [27]. ${ }^{1} \mathrm{H} \mathrm{NMR}\left(\mathrm{CDCl}_{3}, 400 \mathrm{MHz}\right): \delta 7.34-7.22(\mathrm{~m}$, 6H), 7.15-7.12 (m, 4H), 6.07(s, 1H), $6.00(\mathrm{bs}, 1 \mathrm{H}), 5.88(\mathrm{~s}, 1 \mathrm{H}), 5.53(\mathrm{bs}, 1 \mathrm{H}), 3.57-3.44(\mathrm{~m}$, 2H), $3.25(\mathrm{bs}, 1 \mathrm{H}), 3.13(\mathrm{bs}, 1 \mathrm{H}), 2.75-2.52(\mathrm{~m}, 10 \mathrm{H}), 2.38(\mathrm{~s}, 3 \mathrm{H}), 2.36(\mathrm{~s}, 3 \mathrm{H}), 2.12(\mathrm{~s}, 3 \mathrm{H})$, $2.09(\mathrm{~s}, 3 \mathrm{H}), 2.07(\mathrm{~s}, 3 \mathrm{H}), 2.02(\mathrm{~s}, 3 \mathrm{H}), 2.00(\mathrm{~s}, 3 \mathrm{H}), 1.97(\mathrm{~s}, 3 \mathrm{H}), 1.95-1.89(\mathrm{~m}, 2 \mathrm{H}), 1.68(\mathrm{~s}$, 3H), $1.67(\mathrm{~s}, 3 \mathrm{H}) .{ }^{13} \mathrm{C} \mathrm{NMR}\left(\mathrm{CDCl}_{3}, 100 \mathrm{MHz}\right): \delta 171.96,169.99,163.94,153.34,137.99$, $133.45,128.68,128.56,127.92,126.78,126.15,122.25,117.27,112.12,82.10,67.65,40.54$, 
35.56, 30.57, 25.43, 20.44, 13.31, 12.93, 12.09, 11.56, 8.07. MS (EI, $70 \mathrm{eV}): \mathrm{m} / z(\%) 551$ $\left(\mathrm{M}^{+}, 12\right), 509$ (100), 493 (15), 452(21), 250 (14), 203 (53), 105 (18). HRMS m/z calcd for $\mathrm{C}_{29} \mathrm{H}_{33} \mathrm{~N}_{3} \mathrm{O}_{8}[\mathrm{M}+\mathrm{Na}]^{+}$574.2160, found 574.2184

\section{1-(3-methyl-1,2,5-oxadiazol-4-yl $\quad N^{2}$-oxide)-1-(phenethylaminocarbonyl)methyl 6-} benzyloxy-2,5,7,8-tetramethylchroman-2-carboxylate (7c). To a suspension of $2 \mathrm{c}(0.15 \mathrm{~g}$, $0.4 \mathrm{mmol})$ in water $(3.3 \mathrm{~mL} / \mathrm{mmol})$, furoxan aldehyde $(0.05 \mathrm{~g}, 0.4 \mathrm{mmol})$ and phenylethylisocyanide $(0.06 \mathrm{~g}, 0.4 \mathrm{mmol})$ were added. The resulting mixture was vigorously stirred for $4 \mathrm{~h}$ at room temperature. Next, the suspension was treated with aqueous-saturated $\mathrm{NaHCO}_{3}$ solution and extracted with EtOAc. After the work-up, the combined organic layers were dried with $\mathrm{Na}_{2} \mathrm{SO}_{4}$ and evaporated in vacuo. The residue was purified by flash column chromatography ( $\mathrm{SiO}_{2}$, Hexane:EtOAc, 7:3). Yellow oil (20\%). ${ }^{1} \mathrm{H} \mathrm{NMR}\left(\mathrm{CDCl}_{3}, 400 \mathrm{MHz}\right)$ : $\delta$ 7.54-7.51 (m, 4H), 7.47-7.37 (m, 6H), 7.26-7.19 (m, 6H), 7.17-7.13 (m, 4H), $6.13(\mathrm{~s}, 1 \mathrm{H})$, $6.03(\mathrm{t}, J=4.0 \mathrm{~Hz}, 1 \mathrm{H}), 5.89(\mathrm{~s}, 1 \mathrm{H}), 5.48(\mathrm{t}, J=4.0 \mathrm{~Hz}, 1 \mathrm{H}), 4.76(\mathrm{~s}, 2 \mathrm{H}), 4.72(\mathrm{~s}, 2 \mathrm{H}), 3.54$ $3.41(\mathrm{~m}, 2 \mathrm{H}), 3.25-3.18(\mathrm{~m}, 1 \mathrm{H}), 3.12-3.05(\mathrm{~m}, 1 \mathrm{H}), 2.77-2.72(\mathrm{~m}, 3 \mathrm{H}), 2.64-2.48(\mathrm{~m}, 6 \mathrm{H})$, 2.43-2.37 (m, 1H), $2.32(\mathrm{~s}, 3 \mathrm{H}), 2.26(\mathrm{~s}, 3 \mathrm{H}), 2.22(\mathrm{~s}, 6 \mathrm{H}), 2.17(\mathrm{~s}, 3 \mathrm{H}), 2.14(\mathrm{~s}, 3 \mathrm{H}), 2.12(\mathrm{~s}$, 3H), $2.04(\mathrm{~s}, 3 \mathrm{H}), 2.00-1.92(\mathrm{~m}, 2 \mathrm{H}), 1.71(\mathrm{~s}, 3 \mathrm{H}), 1.68(\mathrm{~s}, 3 \mathrm{H}) .{ }^{13} \mathrm{C} \mathrm{NMR}\left(\mathrm{CDCl}_{3}, 100\right.$ MHz): $\delta=172.4,163.8,153.7,149.6,148.2,138.2,128.9,128.0,127.7,125.5,125.2,122.6$, $122.4,122.1,117.7,112.6,99.6,78.4,74.8,68.3,67.2,41.5,41.2,40.6,40.5,36.2,36.0,30.8$, 30.7, 25.7, 25.5, 21.3, 13.7, 13.3, 13.2, 12.9, 12.4. MS (EI, $70 \mathrm{eV}): m / z(\%) 599\left(\mathrm{M}^{+}, 10\right), 508$ (89), 250 (25), 203 (76), 105 (49), 91 (100). HRMS m/z calcd for $\mathrm{C}_{34} \mathrm{H}_{37} \mathrm{~N}_{3} \mathrm{O}_{7}[\mathrm{M}+\mathrm{H}]^{+}$ 599.2870, found 599.2854.

\section{1-(3-methyl-1,2,5-oxadiazol-4-yl $\quad N^{2}$-oxide)-1-(benzylaminocarbonyl)methyl 6-hydroxy-} 2,5,7,8-tetramethylchroman-2-carboxylate (7d). Yellow oil $(62 \%){ }^{1} \mathrm{H} \mathrm{NMR}\left(\mathrm{CDCl}_{3}, 400\right.$ MHz): $\delta 7.39-7.25(\mathrm{~m}, 6 \mathrm{H}), 7.19-7.17(\mathrm{~m}, 2 \mathrm{H}), 7.05-7.03(\mathrm{~m}, 2 \mathrm{H}), 6.49(\mathrm{t}, J=4.0 \mathrm{~Hz}, 1 \mathrm{H})$, $6.26(\mathrm{~s}, 1 \mathrm{H}), 6.04(\mathrm{~s}, 1 \mathrm{H}), 5.08(\mathrm{t}, J=4.0 \mathrm{~Hz}, 1 \mathrm{H}), 4.50-4.46(\mathrm{~m}, 1 \mathrm{H}), 4.45(\mathrm{~s}, 1 \mathrm{H}), 4.43(\mathrm{~s}$, 
1H), 4.33-4.29 (m, 1H), 4.20-4.14 (m, 1H), 4.08-4.04 (m, 1H), 2.74-2.40 (m, 6H), 2.17 (s, 3H), $2.14(\mathrm{~s}, 3 \mathrm{H}), 2.06(\mathrm{~s}, 6 \mathrm{H}), 2.03(\mathrm{~s}, 3 \mathrm{H}), 1.99(\mathrm{~s}, 3 \mathrm{H}), 1.98(\mathrm{~s}, 3 \mathrm{H}), 1.96(\mathrm{~s}, 3 \mathrm{H}), 1.95-1.92$ $(\mathrm{m}, 2 \mathrm{H}), 1.71(\mathrm{~s}, 6 \mathrm{H}) .{ }^{13} \mathrm{C} \mathrm{NMR}\left(\mathrm{CDCl}_{3}, 100 \mathrm{MHz}\right): \delta 172.6,172.3,164.6,164.2,153.7$, $153.4,145.9,147.7,145.4,145.3,137.0,136.8,128.8,128.6,127.8,127.5,127.3,126.6$, $122.3,122.1,121.6,119.6,117.1,117.0,112.3,112.1,77.7,77.2,67.4,66.7,43.4,43.1,31.1$, 30.6, 25.8, 25.4, 20.9, 20.7, 12.2, 12.1, 11.7, 11.6, 11.1. MS (EI, $70 \mathrm{eV}): \mathrm{m} / z(\%) 495\left(\mathrm{M}^{+}\right.$, 39), 438 (14), 250 (11), 205 (100), 189(16), 164 (19), 91 (48). HRMS m/z calcd for $\mathrm{C}_{27} \mathrm{H}_{33} \mathrm{~N}_{3} \mathrm{O}_{6}[\mathrm{M}+\mathrm{H}]^{+}$495.2369, found 495.2353.

1-(3-methyl-1,2,5-oxadiazol-4-yl $\quad N^{2}$-oxide)-1-(tert-butylaminocarbonyl)methyl $\quad 6$ hydroxy-2,5,7,8-tetramethylchroman-2-carboxylate (7e). Yellow oil (80\%). ${ }^{1} \mathrm{H}-\mathrm{NMR}$ $\left(\mathrm{CDCl}_{3}, 400 \mathrm{MHz}\right): \delta 6.07(\mathrm{bs}, 1 \mathrm{H}), 6.02(\mathrm{~s}, 2 \mathrm{H}), 5.78(\mathrm{bs}, 1 \mathrm{H}), 2.75-2.47(\mathrm{~m}, 6 \mathrm{H}), 2.23(\mathrm{~s}$, 3H), 2.19 (s, 9H), 2.12 (s, 3H), 2.07 (s, 3H), 1.96-1.92 (m, 2H), $1.73(\mathrm{~s}, 3 \mathrm{H}), 1.67$ (s, 3H), $1.37(\mathrm{~s}, 9 \mathrm{H}), 1.23(\mathrm{~s}, 9 \mathrm{H}) .{ }^{13} \mathrm{C} \mathrm{NMR}\left(\mathrm{CDCl}_{3}, 100 \mathrm{MHz}\right): \delta 172.5,163.1,163.0,154.0,153.7$, $145.8,145.7,145.3,144.9,122.1,121.7,116.6,112.1,77.2,67.7,67.4,52.2,52.1,31.1,30.4$, 28.7, 28.3, 25.7, 25.4, 20.7, 20.6, 12.3, 12.0, 11.9, 11.3, 11.2. MS (EI, $70 \mathrm{eV}): \mathrm{m} / \mathrm{z}(\%) 461$ (M+ $\left.\mathrm{M}^{+}, 55\right), 404$ (27), 250 (20), 205 (100), 189(16), 164 (20), 57 (40). HRMS m/z calcd for $\mathrm{C}_{23} \mathrm{H}_{31} \mathrm{~N}_{3} \mathrm{O}_{7}[\mathrm{M}+\mathrm{H}]^{+}$461.2162, found 461.2155.

\section{1-(3-methyl-1,2,5-oxadiazol-4-yl $\quad N^{2}$-oxide)-1-(cyclohexylaminocarbonyl)methyl $\quad$ 6-} hydroxy-2,5,7,8- tetramethylchroman-2-carboxylate (7f). Yellow solid (87\%). mp 92.0$94.0{ }^{\circ} \mathrm{C} .{ }^{1} \mathrm{H} \mathrm{NMR}\left(\mathrm{CDCl}_{3}, 400 \mathrm{MHz}\right): \delta 6.16(\mathrm{~s}, 1 \mathrm{H}), 6.01(\mathrm{~s}, 1 \mathrm{H}), 5.99(\mathrm{~d}, \mathrm{~J}=4 \mathrm{~Hz}, 1 \mathrm{H}), 5.50$ $(\mathrm{d}, \mathrm{J}=4 \mathrm{~Hz}, 1 \mathrm{H}), 3.79-3.71(\mathrm{~m}, 1 \mathrm{H}), 3.66-6.58(\mathrm{~m}, 1 \mathrm{H}), 2.77-2.43(\mathrm{~m}, 6 \mathrm{H}), 2.25(\mathrm{~s}, 3 \mathrm{H}), 2.23$ (s, 3H), $2.21(\mathrm{~s}, 6 \mathrm{H}), 2.20(\mathrm{~s}, 3 \mathrm{H}), 2.13(\mathrm{~s}, 3 \mathrm{H}), 2.08(\mathrm{~s}, 3 \mathrm{H}), 2.02(\mathrm{~s}, 3 \mathrm{H}), 1.98-1.89(\mathrm{~m}, 2 \mathrm{H})$, 1.82-1.78(m, 3H), $1.73(\mathrm{~s}, 3 \mathrm{H}), 1.71-1.65(\mathrm{~m}, 3 \mathrm{H}), 1.68(\mathrm{~s}, 3 \mathrm{H}), 1.42-1.20(\mathrm{~m}, 7 \mathrm{H}), 1.16-0.99$ $(\mathrm{m}, 4 \mathrm{H}), 0.94-0.88(\mathrm{~m}, 1 \mathrm{H}), 0.83-0.74(\mathrm{~m}, 1 \mathrm{H}), 0.68-0.60(\mathrm{~m}, 1 \mathrm{H}) .{ }^{13} \mathrm{C} \mathrm{NMR}\left(\mathrm{CDCl}_{3}, 100\right.$ MHz): $\delta 172.6,172.4,162.9,153.7,153.7,153.6,146.1,145.7,145.3,145.0,122.1,121.9$, 
$121.8,121.7,119.2,118.9,116.8,116.7,112.2,77.4,67.3,66.9,48.6,48.4,32.7,32.6,32.3$, $32.1,31.1,30.5,26.1,25.5,25.3,25.1,25.0,24.8,24.7,20.9,20.7,12.4,12.3,12.0,11.9$, 11.4, 11.2, 8.0, 7.6. MS (EI, $70 \mathrm{eV}): m / z(\%) 487\left(\mathrm{M}^{+}, 73\right), 430$ (39), 250 (32), 205 (100), 189(22), 164 (34), 83 (20). HRMS $m / z$ calcd for $\mathrm{C}_{25} \mathrm{H}_{33} \mathrm{~N}_{3} \mathrm{O}_{7}[\mathrm{M}+\mathrm{H}]^{+}$487.2319, found 487.2326

\section{1-(3-methyl-1,2,5-oxadiazol-4-yl $N^{2}$-oxide)-1-((2-morpholinoethyl)aminocarbonyl)methyl} 6-hydroxy-2,5,7,8- tetramethylchroman-2-carboxylate (7g) Yellow oil (9\%). ${ }^{1} \mathrm{H}$ NMR $\left(\mathrm{CDCl}_{3}, 400 \mathrm{MHz}\right): \delta 6.82(\mathrm{t}, J=4.0 \mathrm{~Hz}, 1 \mathrm{H}), 6.06(\mathrm{~s}, 1 \mathrm{H}), 3.74-3.71(\mathrm{~m}, 4 \mathrm{H}), 3.47-3.39(\mathrm{~m}$, 1H), 3.33-3.26 (m, 1H), 2.69-2.55 (m, 2H), 2.52-2.48 (m, 7H), $2.18(\mathrm{~s}, 3 \mathrm{H}), 2.15(\mathrm{~s}, 3 \mathrm{H})$, $2.06(\mathrm{~s}, 3 \mathrm{H}), 2.00-1.97(\mathrm{~m}, 1 \mathrm{H}), 1.95(\mathrm{~s}, 3 \mathrm{H}), 1.74(\mathrm{~s}, 3 \mathrm{H}) \cdot{ }^{13} \mathrm{C} \mathrm{NMR}\left(\mathrm{CDCl}_{3}, 100 \mathrm{MHz}\right): \delta$ $172.6,153.6,145.9,122.0,120.0,116.8,111.7,77.4,67.5,66.5,56.5,53.0,35.6,30.1,23.9$, 19.9, 11.3, 9.8, 6.4. MS (EI, $70 \mathrm{eV}): m / z(\%) 518\left(\mathrm{M}^{+}, 10\right), 355$ (20), 250 (2), 205 (5), 100 (100). HRMS $m / z$ calcd for $\mathrm{C}_{25} \mathrm{H}_{34} \mathrm{~N}_{4} \mathrm{O}_{8}[\mathrm{M}+\mathrm{H}]^{+}$518.2377, found 518.2389.

\section{1-(3-((3-(phenylsulfonyl)-1,2,5-oxadiazol-4-yl}

$N^{2}$-oxide)oxy)phenyl)-1-(tertbutylaminocarbonyl)methyl 6-hydroxy-2,5,7,8- tetramethylchroman-2-carboxylate (7h). Yellow solid (53\%). mp 52.0-54.0 ${ }^{\circ} \mathrm{C} .{ }^{1} \mathrm{H}$ NMR $\left(\mathrm{CDCl}_{3}, 400 \mathrm{MHz}\right): \delta 8.14-8.09(\mathrm{~m}, 4 \mathrm{H})$, 7.83-7.79 (m, 2H), 7.69-7.65 (m, 4H), 7.55-7.38 (m, 4H), 7.31-7.29 (m, 1H), 7.23-7.21 (m, 1H), 7.10-7.07 (m, 1H), 7.01-6.99 (m, 1H), $6.11(\mathrm{bs}, 1 \mathrm{H}), 5.99(\mathrm{~s}, 1 \mathrm{H}), 5.94(\mathrm{~s}, 1 \mathrm{H}), 5.55(\mathrm{bs}$, 1H), $4.75(\mathrm{~s}, 1 \mathrm{H}), 4.42(\mathrm{~s}, 1 \mathrm{H}), 2.74-2.45(\mathrm{~m}, 6 \mathrm{H}), 2.26(\mathrm{~s}, 3 \mathrm{H}), 2.24(\mathrm{~s}, 3 \mathrm{H}), 2.19(\mathrm{~s}, 3 \mathrm{H})$, $2.17(\mathrm{~s}, 3 \mathrm{H}), 2.09(\mathrm{~s}, 3 \mathrm{H}), 1.97(\mathrm{~s}, 3 \mathrm{H}), 1.93-1.84(\mathrm{~m}, 2 \mathrm{H}), 1.71(\mathrm{~s}, 3 \mathrm{H}), 1.61(\mathrm{~s}, 3 \mathrm{H}), 1.35(\mathrm{~s}$, 9H), $1.13(\mathrm{~s}, 9 \mathrm{H}) .{ }^{13} \mathrm{C} \mathrm{NMR}\left(\mathrm{CDCl}_{3}, 100 \mathrm{MHz}\right): \delta$ 172.7, 172.6, 166.4, 166.3, 152.6, 152.2, $145.6,145.5,145.1,145.0,138.4,138.1,137.9,137.7,135.9,135.8,129.9,129.8,128.7$, $128.6,125.7,125.1,122.2,122.0,121.7,119.9,119.7,118.8,118.2,117.9,99.9,99.8,75.1$, 51.6, 51.4, 30.3, 28.7, 28.3, 25.8, 20.8, 20.7, 12.0, 11.3, 11.1. MS (EI, $70 \mathrm{eV}): \mathrm{m} / z(\%) 679$ 
(M+, 3), 538 (3), 524 (6), 250 (12), 205 (26), 164 (7), 57 (100). HRMS m/z calcd for $\mathrm{C}_{34} \mathrm{H}_{37} \mathrm{~N}_{3} \mathrm{O}_{10} \mathrm{~S}[\mathrm{M}+\mathrm{H}]^{+}$679.2210, found 679.2197.

\section{1-(phenyl)-1-(benzylaminocarbonyl)methyl 6-hydroxy-2,5,7,8-tetramethylchroman-2-}

carboxylate (7i). This compound was isolated as by product of the Ugi reaction performed to obtained 8a. Yellow solid. mp 54.0-56.0 ${ }^{\circ} \mathrm{C} .{ }^{1} \mathrm{H}$ NMR $\left(\mathrm{CDCl}_{3}, 400 \mathrm{MHz}\right): \delta$ 7.48-7.36 (m, 8H), 7.33-7.28 (m, 6H), 7.21-7.19 (m, 3H), 7.05-7.03 (m, 3H), 6.54 (bs, 1H), $6.22(\mathrm{~s}, 1 \mathrm{H})$, $6.02(\mathrm{~s}, 1 \mathrm{H}), 5.61(\mathrm{bs}, 1 \mathrm{H}), 4.56-4.52(\mathrm{~m}, 1 \mathrm{H}), 4.42-4.38(\mathrm{~m}, 1 \mathrm{H}), 4.22-4.18(\mathrm{~m}, 1 \mathrm{H}), 3.96-$ $3.91(\mathrm{~m}, 1 \mathrm{H}), 2.70-2.46(\mathrm{~m}, 6 \mathrm{H}), 2.20(\mathrm{~s}, 3 \mathrm{H}), 2.16(\mathrm{~s}, 3 \mathrm{H}), 2.14(\mathrm{~s}, 3 \mathrm{H}), 2.03(\mathrm{~s}, 3 \mathrm{H}), 1.98(\mathrm{~s}$, 3H), 1.96-1.93 (m, 2H), 1.91 (s, 3H), 1.69 (s, 3H), 1.67 (s, 3H). ${ }^{13} \mathrm{C} \mathrm{NMR}\left(\mathrm{CDCl}_{3}, 100 \mathrm{MHz}\right)$ : $\delta 174.5,172.8,172.4,168.5,168.0,145.9,144.3,138.2,137.9,135.5,128.9,128.8,128.7$, $128.6,128.5,128.4,127.6,127.5,127.3,127.0,126.9,126.3,122.3,122.2,121.8,121.7$, $119.3,118.1,78.5,77.7,76.3,75.2,42.9,42.5,31.1,30.7,29.6,25.9,25.7,24.7,21.0,20.6$, 12.3, 12.0, 11.9, 11.8, 11.3, 11.1. MS (EI, $70 \mathrm{eV}): m / z(\%) 473\left(\mathrm{M}^{+}, 16\right), 249$ (4), 205 (100), 105 (3), 91 (17), 77 (2). HRMS $m / z$ calcd for $\mathrm{C}_{29} \mathrm{H}_{31} \mathrm{NO}_{5}[\mathrm{M}+\mathrm{H}]^{+}$473.2202, found 473.2189 .

\section{1-(phenyl)-1-(phenethylaminocarbonyl)methyl 6-hydroxy-2,5,7,8-tetramethylchroman-}

2-carboxylate (7j). This compound was isolated as by product of the Ugi reaction performed to obtained 8g. Yellow oil. ${ }^{1} \mathrm{H}$ NMR $\left(\mathrm{CDCl}_{3}, 400 \mathrm{MHz}\right): \delta 7.54(\mathrm{t}, J=4.0 \mathrm{~Hz}, 1 \mathrm{H}), 7.46-7.37$ (m, 10H), 7.28-7.19 (m, 5H), 7.16-7.11 (m, 5H), $6.34(\mathrm{t}, J=4.0 \mathrm{~Hz}, 1 \mathrm{H}), 6.24(\mathrm{~s}, 1 \mathrm{H}), 6.03$ (s, 1H), 3.70-3.53 (m, 4H), 2.91-2.83 (m, 4H), 2.59-2.51 (m, 2H), 2.33-2.26 (m, 1H), 2.18$2.10(\mathrm{~m}, 1 \mathrm{H}), 2.06(\mathrm{~s}, 3 \mathrm{H}), 2.05(\mathrm{~s}, 3 \mathrm{H}), 2.03(\mathrm{~s}, 3 \mathrm{H}), 2.01(\mathrm{~s}, 3 \mathrm{H}), 1.87(\mathrm{~s}, 3 \mathrm{H}), 1.74-1.67(\mathrm{~m}$, 2H), $1.42(\mathrm{~s}, 3 \mathrm{H}), 1.33(\mathrm{~s}, 3 \mathrm{H}), 1.28(\mathrm{~s}, 3 \mathrm{H}) .{ }^{13} \mathrm{C} \mathrm{NMR}\left(\mathrm{CDCl}_{3}, 100 \mathrm{MHz}\right): \delta 187.6,187.5$, $187.4,187.2,175.6,175.0,167.9,167.7,143.0,142.6,141.2,141.1,140.8,140.6,140.3$, $140.1,139.0,138.4,135.3,134.8,129.3,129.0,128.9,128.8,128.7,128.6,128.4,127.5,127.3$, $126.6,126.3,77.1,74.5,74.4,41.0,40.5,38.0,37.7,35.4,35.3,27.3,26.3,21.9,21.1,12.5$, 
12.4, 12.3, 12.2, 12.0, 11.9. MS (EI, $70 \mathrm{eV}): m / z(\%) 487\left(\mathrm{M}^{+}, 100\right), 249$ (49), 205 (69), 164

(5), 105 (25), 77 (4). HRMS $m / z$ calcd for $\mathrm{C}_{30} \mathrm{H}_{33} \mathrm{NO}_{5}[\mathrm{M}+\mathrm{H}]^{+}$487.2359, found 487.2375.

\section{1-(tert-butylaminocarbonyl)-1-(3-(4-nitrooxybutoxy)phenyl)methyl 6-methoxy-2,5,7,8-}

tetramethylchroman-2-carboxylate (7k). This compound was isolated as by product of the Ugi reaction performed to obtained 8o. Yellow oil. ${ }^{1} \mathrm{H}$ NMR $\left(\mathrm{CDCl}_{3}, 400 \mathrm{MHz}\right): \delta 7.28(\mathrm{~m}$, 1H), 7.08 (t, $J=7.6 \mathrm{~Hz}, 1 \mathrm{H}), 6.99(\mathrm{~d}, J=8.0 \mathrm{~Hz}, 1 \mathrm{H}), 6.94(\mathrm{~m}, 1 \mathrm{H}), 6.99$ (dd, $J=2.8 \mathrm{~Hz}, J=$ $8.4 \mathrm{~Hz}, 1 \mathrm{H}), 6.79(\mathrm{dd}, J=2.8 \mathrm{~Hz}, J=8.0 \mathrm{~Hz}, 1 \mathrm{H}), 6.72(\mathrm{~m}, 1 \mathrm{H}), 6.42(\mathrm{~d}, J=7.2 \mathrm{~Hz}, 1 \mathrm{H})$, $5.98(\mathrm{~s}, \mathrm{NH}, 1 \mathrm{H}), 5.93(\mathrm{~s}, 1 \mathrm{H}), 5.84(\mathrm{~s}, 1 \mathrm{H}), 5.59(\mathrm{~s}, \mathrm{NH}, 1 \mathrm{H}), 4.58(\mathrm{~m}, 4 \mathrm{H}), 4.02(\mathrm{t}, J=5.6$ Hz, 2H), $3.92(\mathrm{t}, J=5.6 \mathrm{~Hz}, 2 \mathrm{H}), 3.66(\mathrm{~s}, 3 \mathrm{H}), 3.63(\mathrm{~s}, 3 \mathrm{H}), 2.65-2.38(\mathrm{~m}, 6 \mathrm{H}), 2.24(\mathrm{~s}, 3 \mathrm{H})$, $2.23(\mathrm{~s}, 3 \mathrm{H}), 2.22(\mathrm{~s}, 3 \mathrm{H}), 2.21(\mathrm{~s}, 3 \mathrm{H}), 2.12(\mathrm{~s}, 3 \mathrm{H}), 2.05(\mathrm{~s}, 3 \mathrm{H}), 1.93(\mathrm{~m}, 10 \mathrm{H}), 1.69(\mathrm{~s}, 3 \mathrm{H})$, $1.61(\mathrm{~s}, 3 \mathrm{H}), 1.60(\mathrm{~s}, 3 \mathrm{H}), 1.32(\mathrm{~s}, 9 \mathrm{H}), 1.14(\mathrm{~s}, 9 \mathrm{H}) .{ }^{13} \mathrm{C} \mathrm{NMR}\left(\mathrm{CDCl}_{3}, 100 \mathrm{MHz}\right): \delta$ 175.1, $168.5,158.4,148.2,146.7,146.6,136.3,129.1,127.9,127.5,127.3,127.1,123.0$, $122.1,118.5,115.6,114.8,114.3,80.7,72.9,71.1,69.2,66.7,60.4,51.4,32.4,28.6,27.7$, 25.5, 23.8, 21.1, 12.5, 11.7, 11.5. MS (EI, $70 \mathrm{eV}): m / z(\%) 586\left(\mathrm{M}^{+}, 58\right), 541(8), 481(19)$, 264 (17), 247 (17), 219 (100), 57 (31).

General procedure for Ugi products (8a-8s). Method A (microwave-assisted). A glass tube was charged sequentially with aldehyde $(0.6 \mathrm{mmol})$, amine $(0.6 \mathrm{mmol})$, chromancarboxylic acid $(0.6 \mathrm{mmol})$ and isocyanide $(0.6 \mathrm{mmol})$, under solvent free conditions or distilled water or $\mathrm{pH} 5.5$ buffer aqueous solution or EtOH. The sealed test tube was heated $15-45 \min$ at 60 or $100{ }^{\circ} \mathrm{C}$ by microwave irradiation. The vial was allowed to cool, and the crude reaction mixture was treated with aqueous-saturated $\mathrm{NaHCO}_{3}$ solution and extracted with EtOAc. The organic layer was washed with brine, dried with $\mathrm{Na}_{2} \mathrm{SO}_{4}$ and evaporated under reduced pressure. The residue was purified by flash column chromatography $\left(\mathrm{SiO}_{2}\right.$, Hexane/EtOAc). Method B. Aldehyde $(0.6 \mathrm{mmol})$, amine $(0.6 \mathrm{mmol})$, chromancarboxylic acid $(0.6 \mathrm{mmol})$ and isocyanide $(0.6 \mathrm{mmol})$ were added in that specific order, in 
$\mathrm{NaOAc} / \mathrm{HOAc}$ Buffer $\mathrm{pH} 5.5$ or distilled water or EtOH, and was stirred under orbital agitation for $24 \mathrm{~h}$ or $48 \mathrm{~h}$. The reaction mixture was treated with $\mathrm{NaHCO}_{3}$ saturated solution $(50 \mathrm{~mL})$ and extracted with EtOAc. The combined organic layers were washed with brine and dried with $\mathrm{Na}_{2} \mathrm{SO}_{4}$, filtered and the solvent evaporated under reduced pressure. Purification by flash column chromatography $\left(\mathrm{SiO}_{2}\right.$, hexane/EtOAc). Method C (ultrasound-assisted). Aldehyde $(0.6 \mathrm{mmol})$, amine $(0.6 \mathrm{mmol})$, chromancarboxylic acid $(0.6 \mathrm{mmol})$ and isocyanide (0.6 mmol) were sequentially introduced into a round-bottom flask; then it was placed inside an ultrasound apparatus (Ultrasons-H, J.P. Selecta.) preheated at $60^{\circ} \mathrm{C}$. It was exposed for $6 \mathrm{~h}$ at $720 \mathrm{~W}$ and $50 / 60 \mathrm{~Hz}$. The reaction mixture was then allowed to cool, treated with $\mathrm{NaHCO}_{3}$ saturated solution $(50 \mathrm{~mL})$ and extracted with EtOAc. The combined organic layers were washed with brine and dried with $\mathrm{Na}_{2} \mathrm{SO}_{4}$, filtered and the solvent evaporated under reduced pressure. Purification by flash column chromatography $\left(\mathrm{SiO}_{2}\right.$, hexane/EtOAc).

\section{$N$-((1-phenyl-1-benzylaminocarbonyl)methyl)- $N$-phenyl-6-hydroxy-2,5,7,8-}

tetramethylchroman-2-carboxamide (8a). This compound was obtained by method A or B. The crude product was purified by flash column chromatography (hexane:EtOAc, 8:2) to rendered the desired Ugi product $(\mathbf{8 a})$ as a white solid (mp 170.0-172.0 ${ }^{\circ} \mathrm{C}$ ) and Passerini product (7i) as a yellow solid. ${ }^{1} \mathrm{H}$ NMR $\left(\mathrm{CDCl}_{3}, 400 \mathrm{MHz}\right): \delta$ 7.36-7.26 (m, 10H), 7.23-7.12 (m, 13H), 7.09-7.04 (m, 7H), $6.57(\mathrm{sa}, 1 \mathrm{H}), 5.97(\mathrm{sa}, 1 \mathrm{H}), 5.72(\mathrm{~s}, 2 \mathrm{H}), 4.51-4.48(\mathrm{~m}, 4 \mathrm{H})$, 2.83-2.69 (m, 3H), 2.62-2.53 (m, 3H), $2.15(\mathrm{~s}, 3 \mathrm{H}), 2.12(\mathrm{~s}, 3 \mathrm{H}), 2.08(\mathrm{~s}, 3 \mathrm{H}), 2.05(\mathrm{~s}, 3 \mathrm{H})$, $1.73(\mathrm{~s}, 3 \mathrm{H}), 1.69(\mathrm{~s}, 3 \mathrm{H}), 1.61-1.54(\mathrm{~m}, 2 \mathrm{H}), 1.29(\mathrm{~s}, 3 \mathrm{H}), 1.26(\mathrm{~s}, 3 \mathrm{H}) .{ }^{13} \mathrm{C} \mathrm{NMR}\left(\mathrm{CDCl}_{3}\right.$, $100 \mathrm{MHz}): \delta 175.1,174.9,169.5,169.2,144.8,144.5,138.3,138.1,134.7,134.3,130.3$, $129.7,128.6,128.5,128.4,128.3,128.2,128.1,128.0,127.6,127.5,127.3,127.2,127.1$, $122.7,122.6,118.3,118.2,80.4,80.2,69.0,43.8,43.7,32.7,32.4,27.7,27.6,21.2,21.1,12.1$, 12.0, 11.7, 11.6, 11.3. MS (EI, $70 \mathrm{eV}): m / z(\%) 548\left(\mathrm{M}^{+}, 17\right), 205$ (100). HRMS $m / z$ calcd for $\mathrm{C}_{35} \mathrm{H}_{36} \mathrm{~N}_{2} \mathrm{O}_{4}[\mathrm{M}+\mathrm{H}]^{+}$548,2675, found 548.2686. 


\section{$N$-(1-phenyl-1-(tert-butylaminocarbonyl)methyl)- $N$-phenyl-6-hydroxy-2,5,7,8-}

tetramethylchroman-2-carboxamide (8b). This compound was obtained by method B. The crude product was purified by flash column chromatography (hexane:EtOAc, 8:2) to rendered the desired Ugi product (8b) as a white solid (77\%). mp 162.0-164.0 ${ }^{\circ} \mathrm{C} .{ }^{1} \mathrm{H}$ NMR $\left(\mathrm{CDCl}_{3}\right.$, $400 \mathrm{MHz}): \delta 7.43-7.35(\mathrm{~m}, 1 \mathrm{H}), 7.28-7.23(\mathrm{~m}, 1 \mathrm{H}), 7.22-7.13(\mathrm{~m}, 10 \mathrm{H}), 7.11-7.10(\mathrm{~m}, 3 \mathrm{H})$, 7.04-7.02 (m, 3H), 6.95-6.94 (m, 2H), $6.40(\mathrm{sa}, 1 \mathrm{H}), 5.63(\mathrm{~s}, 1 \mathrm{H}), 5.57(\mathrm{sa}, 1 \mathrm{H}), 5.45(\mathrm{~s}, 1 \mathrm{H})$, 2.76-2.68 (m, 2H), 2.61-2.56 (m, 1H), 2.53-2.51 (m, 2H), $2.16(\mathrm{~s}, 3 \mathrm{H}), 2.15(\mathrm{~s}, 3 \mathrm{H}), 2.09(\mathrm{~s}$, 3H), $2.05(\mathrm{~s}, 3 \mathrm{H}), 1.73(\mathrm{~s}, 3 \mathrm{H}), 1.70(\mathrm{~s}, 3 \mathrm{H}), 1.58-1.51(\mathrm{~m}, 2 \mathrm{H}), 1.38(\mathrm{~s}, 9 \mathrm{H}), 1.32(\mathrm{~s}, 9 \mathrm{H})$, $1.28(\mathrm{~s}, 3 \mathrm{H}), 1.25(\mathrm{~s}, 3 \mathrm{H}) .{ }^{13} \mathrm{C} \mathrm{NMR}\left(\mathrm{CDCl}_{3}, 100 \mathrm{MHz}\right): \delta 175.5,174.9,168.7,168.4,145.0$, $144.8,144.5,144.4,142.0,140.6,135.0,134.8,130.0,129.3,128.8,128.7,128.6,128.5$, $128.4,128.3,128.2,128.1,128.0,127.9,127.8,127.3,127.1,126.9,126.8,122.6,122.5$, $120.9,120.7,118.3,118.2,118.1,117.9,80.3,80.1,71.9,69.3,51.4,51.3,32.7,32.5,28.7$, 28.6, 27.7, 27.6, 21.3, 21.2, 12.1, 12.0, 11.7, 11.6, 11.4, 11.3. MS (EI, $70 \mathrm{eV}): \mathrm{m} / \mathrm{z}(\%) 514$ $\left(\mathrm{M}^{+}, 29\right), 403$ (19), 232 (3), 205 (100). HRMS $m / z$ calcd for $\mathrm{C}_{32} \mathrm{H}_{38} \mathrm{~N}_{2} \mathrm{O}_{4}[\mathrm{M}+\mathrm{H}]^{+}$514.2832, found 514.2822.

\section{$N$-((1-phenyl-1-ciclohexylaminocarbonyl)methyl)- $N$-phenyl-6-hydroxy-2,5,7,8-}

tetramethylchroman-2-carboxamide (8c). This compound was obtained by method B. The crude product was purified by flash column chromatography (hexane:EtOAc, 8:2) to rendered the desired Ugi product (8c) as a white solid (60\%). mp 78.0-79.0 ${ }^{\circ} \mathrm{C} .{ }^{1} \mathrm{H}$ NMR $\left(\mathrm{CDCl}_{3}, 400\right.$ MHz): $\delta$ 7.44-7.35 (m, 2H), 7.29-7.18 (m, 6H), 7.16-7.08 (m, 8H), 7.01-6.99 (m, 2H), 6.89$6.85(\mathrm{~m}, 2 \mathrm{H}), 6.34(\mathrm{sa}, 1 \mathrm{H}), 5.75(\mathrm{~s}, 1 \mathrm{H}), 5.59(\mathrm{~s}, 1 \mathrm{H}), 5.55(\mathrm{sa}, 1 \mathrm{H}), 3.90-3.78(\mathrm{~m}, 2 \mathrm{H})$, 2.83-2.79 (m, 1H), 2.77-2.68 (m, 2H), 2.61-2.58 (m, 1H), 2.53-2.51 (m, 2H), $2.15(\mathrm{~s}, 6 \mathrm{H})$, $2.09(\mathrm{~s}, 3 \mathrm{H}), 2.04(\mathrm{~s}, 3 \mathrm{H}), 1.95-1.84(\mathrm{~m}, 4 \mathrm{H}), 1.73(\mathrm{~s}, 3 \mathrm{H}), 1.70(\mathrm{~s}, 3 \mathrm{H}), 1.67-1.53(\mathrm{~m}, 6 \mathrm{H})$, 1.41-1.33 (m, 6H), $1.30(\mathrm{~s}, 3 \mathrm{H}), 1.24(\mathrm{~s}, 3 \mathrm{H}), 1.21-1.09(\mathrm{~m}, 6 \mathrm{H}) .{ }^{13} \mathrm{C} \mathrm{NMR}\left(\mathrm{CDCl}_{3}, 100\right.$ MHz): $\delta 175.6,174.8,168.5,168.3,144.4,140.4,134.9,134.6,130.2,129.45,128.2,128.1$, 
$127.9,127.8,127.3,127.1,122.6,118.3,118.1,118.0,80.4,80.2,68.6,48.6,48.3,32.9,32.8$, $32.7,32.6,32.4,27.7,25.5,24.9,24.8,24.7,21.2,12.1,12.0,11.7,11.5,11.4,11.3$. MS (EI, $70 \mathrm{eV}): m / z(\%) 540\left(\mathrm{M}^{+}, 37\right), 205(100), 182(45)$. HRMS $m / z$ calcd for $\mathrm{C}_{34} \mathrm{H}_{40} \mathrm{~N}_{2} \mathrm{O}_{4}[\mathrm{M}+\mathrm{H}]^{+}$ 544.2988, found 540.2997.

\section{$N$-(1-(3-butenyl)-1-(benzylaminocarbonyl)methyl)- $N$-phenyl-6-hydroxy-2,5,7,8-}

tetramethylchroman-2-carboxamide (8d). This compound was obtained by method B. The crude product was purified by flash column chromatography (hexane:EtOAc, 8:2) to rendered the desired Ugi product (8d) as a white solid (41\%). m.p. 137.0-138.0 ${ }^{\circ} \mathrm{C} .{ }^{1} \mathrm{H}-\mathrm{NMR}\left(\mathrm{CDCl}_{3}\right)$ : $\delta=7.29-7.21(\mathrm{~m}, 8 \mathrm{H}), 7.19-7.13(\mathrm{~m}, 6 \mathrm{H}), 7.09-7.01(\mathrm{~m}, 5 \mathrm{H}), 6.88(\mathrm{sa}, 2 \mathrm{H}), 4.93(\mathrm{sa}, 1 \mathrm{H})$, $4.74(\mathrm{sa}, 1 \mathrm{H}), 4.30-4.25(\mathrm{~m}, 4 \mathrm{H}), 2.63-2.56(\mathrm{~m}, 2 \mathrm{H}), 2.47-2.39(\mathrm{~m}, 4 \mathrm{H}), 2.00(\mathrm{~s}, 3 \mathrm{H}), 1.98(\mathrm{~s}$, 3H), $1.95(\mathrm{~s}, 3 \mathrm{H}), 1.94(\mathrm{~s}, 3 \mathrm{H}), 1.60(\mathrm{~s}, 2 \mathrm{H}), 1.55(\mathrm{~s}, 3 \mathrm{H}), 1.46-1.39(\mathrm{~m}, 5 \mathrm{H}), 1.20(\mathrm{~s}, 3 \mathrm{H})$, $1.18-1.09(\mathrm{~m}, 9 \mathrm{H}), 0.75-0.70(\mathrm{~m}, 6 \mathrm{H}) .{ }^{13} \mathrm{C}-\mathrm{NMR}: \delta=176.4,170.9,170.1,145.1,145.0$, $144.4,144.3,140.1,138.5,138.4,138.1,128.7,128.6,128.4,128.1,127.9,127.7,127.6$, $127.4,127.3,122.7,122.6,121.4,120.9,118.1,117.8,117.4,80.7,80.2,63.9,60.7,43.5$, $43.4,32.8,32.7,28.7,28.2,28.0,27.8,27.7,27.6,22.5,22.4,21.3,21.2,13.9,13.8,12.1$, 12.0, 11.8, 11.7. MS (IE, $70 \mathrm{eV}): m / z(\%) 528\left(\mathrm{M}^{+}, 13\right), 205(100)$. HRMS $m / z$ calcd for $\mathrm{C}_{33} \mathrm{H}_{40} \mathrm{~N}_{2} \mathrm{O}_{4}[\mathrm{M}+\mathrm{H}]^{+}$528,2988, found 528.2963.

\section{$N$-(1-(3-butenyl)-1-(tert-butylaminocarbonyl)methyl)- $N$-phenyl-6-hydroxy-2,5,7,8-}

tetramethylchroman-2-carboxamide (8e). This compound was obtained by method $\mathrm{B}$. The crude product was purified by flash column chromatography (hexane:EtOAc, 8:2) to rendered the desired Ugi product (8e) as a yellow oil (47\%). ${ }^{1} \mathrm{H}$ NMR $\left(\mathrm{CDCl}_{3}, 400 \mathrm{MHz}\right): \delta 7.22-7.05$ (m, 6H), 6.69-6.50 (m, 4H), $4.84(\mathrm{sa}, 2 \mathrm{H}), 4.67(\mathrm{sa}, 1 \mathrm{H}), 2.70-2.60(\mathrm{~m}, 2 \mathrm{H}), 2.51-2.43(\mathrm{~m}$, 4H), 2.01 (s, 3H), 1.99 (s, 6H), $1.93(\mathrm{~s}, 3 \mathrm{H}), 1.59$ (s, 3H), 1.55 (s, 3H), 1.47-1.39 (m, 3H), 1.35-1.30 (m, 2H), $1.25(\mathrm{~s}, 9 \mathrm{H}), 1.22(\mathrm{~s}, 9 \mathrm{H}), 1.15(\mathrm{~s}, 3 \mathrm{H}), 1.13-1.05(\mathrm{~m}, 10 \mathrm{H}), 0.74-0.70(\mathrm{~m}$, 6H). ${ }^{13} \mathrm{C} \mathrm{NMR}\left(\mathrm{CDCl}_{3}, 400 \mathrm{MHz}\right): \delta 176.7,176.6,169.8,169.3,145.0,144.3,139.7,138.3$, 
$129.3,128.5,128.3,127.9,127.7,122.6,120.9,118.6,118.2,118.0,117.9,117.5,115.1,80.5$, $80.2,61.3,50.9,32.8,32.7,28.8,28.7,28.6,28.2,28.0,27.9,27.8,27.6,22.6,22.5,21.4$, 14.0, 13.9, 12.1, 12.0, 11.7, 11.6, 11.4, 11.3. MS (EI, $70 \mathrm{eV}): m / z(\%) 494\left(\mathrm{M}^{+}, 21\right), 205$ (100), 162 (27). HRMS $m / z$ calcd for $\mathrm{C}_{30} \mathrm{H}_{42} \mathrm{~N}_{2} \mathrm{O}_{4}[\mathrm{M}+\mathrm{H}]^{+} 494.3145$, found 494.3156 .

\section{$N$-(1-(butenyl)-1-(cyclohexylaminocarbonyl)methyl)- $N$-phenyl-6-hydroxy-2,5,7,8-}

tetramethylchroman-2-carboxamide (8f). This compound was obtained by method $\mathrm{B}$. The crude product was purified by flash column chromatography (hexane:EtOAc, 8:2) to rendered the desired Ugi product (8f) as a white solid (39\%). mp 58.0-60.0 ${ }^{\circ} \mathrm{C} .{ }^{1} \mathrm{H}$ NMR $\left(\mathrm{CDCl}_{3}, 400\right.$ MHz): $\delta 7.33-6.94(\mathrm{~m}, 10 \mathrm{H}), 6.75(\mathrm{sa}, 1 \mathrm{H}), 6.61$ (sa, 1H), 4.99 (sa, 1H), 4.81 (sa, 1H), 3.79$3.69(\mathrm{~m}, 2 \mathrm{H}), 2.81-2.72(\mathrm{~m}, 2 \mathrm{H}), 2.62-2.55(\mathrm{~m}, 4 \mathrm{H}), 2.13(\mathrm{~s}, 3 \mathrm{H}), 2.11(\mathrm{~s}, 6 \mathrm{H}), 2.06(\mathrm{~s}, 3 \mathrm{H})$, $1.96-1.81(\mathrm{~m}, 4 \mathrm{H}), 1.77-1.73(\mathrm{~m}, 4 \mathrm{H}), 1.71(\mathrm{~s}, 3 \mathrm{H}), 1.66(\mathrm{~s}, 3 \mathrm{H}), 1.57-1.44(\mathrm{~m}, 6 \mathrm{H}), 1.39-$ $1.32(\mathrm{~m}, 9 \mathrm{H}), 1.29(\mathrm{~s}, 3 \mathrm{H}), 1.25-1.17(\mathrm{~m}, 10 \mathrm{H}), 0.94-0.89(\mathrm{~m}, 4 \mathrm{H}), 0.87-0.82(\mathrm{~m}, 6 \mathrm{H}) .{ }^{13} \mathrm{C}$ $\operatorname{NMR}\left(\mathrm{CDCl}_{3}, 100 \mathrm{MHz}\right): \delta 175.9,169.8,169.3,145.1,144.4,144.3,128.4,128.3,127.9$, 127.7, 122.6, 121.0, 118.3, 118.2, 117.8, 117.4, 80.6, 80.1, 61.1, 47.9, 47.7, 33.2, 33.1, 33.0, $32.8,32.7,29.4,28.7,28.2,28.0,27.9,27.8,27.6,25.6,25.5,24.9,24.8,24.7,24.6,22.6$, $22.5,21.4,14.0,13.9,12.2,12.1,11.8,11.7,11.4,11.3 . \mathrm{MS}(\mathrm{EI}, 70 \mathrm{eV}): m / z(\%) 520\left(\mathrm{M}^{+}\right.$, 27), 421 (4), 289 (10), 205 (100). HRMS $m / z$ calcd for $\mathrm{C}_{32} \mathrm{H}_{44} \mathrm{~N}_{2} \mathrm{O}_{4}[\mathrm{M}+\mathrm{H}]^{+}$520.3301, found 520.3284

\section{$N$-(1-(phenyl)-1(phenethylaminocarbonyl)methyl)- $N$-(ethyloxycarbonylmethyl)-6-}

hydroxy-2,5,7,8-tetramethylchroman-2-carboxamide (8g). This compound was obtained by method A or B. The crude product was purified by flash column chromatography (hexane:EtOAc, 8:2) to rendered the desired Ugi product $(\mathbf{8 g})$ as a yellow oil and the Passerini product (7j) as a yellow oil. 8g: ${ }^{1} \mathrm{H}$ NMR $\left(\mathrm{CDCl}_{3}, 400 \mathrm{MHz}\right): \delta 7.45-7.09$ (m, 20H), 6.98 (s, 1H), $6.76(\mathrm{~s}, 1 \mathrm{H}), 4.25-4.3 .44(\mathrm{~m}, 8 \mathrm{H}), 3.15-2.95(\mathrm{~m}, 4 \mathrm{H}), 2.85-2.45(\mathrm{~m}, 10 \mathrm{H}), 2.18(\mathrm{~s}, 3 \mathrm{H})$, $2.16(\mathrm{~s}, 3 \mathrm{H}), 2.15(\mathrm{~s}, 3 \mathrm{H}), 2.14(\mathrm{~s}, 3 \mathrm{H}), 2.09(\mathrm{~s}, 3 \mathrm{H}), 2.03(\mathrm{~s}, 3 \mathrm{H}), 1.83(\mathrm{~s}, 3 \mathrm{H}), 1.68-1.66(\mathrm{~m}$, 
2H), $1.65(\mathrm{~s}, 3 \mathrm{H}), 1.26(\mathrm{~s}, 3 \mathrm{H}), 1.24(\mathrm{~s}, 3 \mathrm{H}) .{ }^{13} \mathrm{C} \mathrm{NMR}\left(\mathrm{CDCl}_{3}, 100 \mathrm{MHz}\right): \delta 175.9,174.3$, $171.6,171.2,170.6,168.9,167.6,135.4,130.0,129.0,128.9,128.8,128.7,126.4,126.2$, $122.7,121.6,121.3,119.0,118.7,118.4,118.0,80.5,79.9,64.6,64.2,61.8,61.7,60.4,49.1$, $48.9,40.6,40.4,35.4,34.7,32.8,31.7,27.3,25.2,21.1,20.9,14.2,13.9,12.3,12.2,12.1$, 11.4, 11.3. MS (EI, $70 \mathrm{eV}): m / z(\%) 572\left(\mathrm{M}^{+}, 11\right), 526(14), 451$ (3), 341 (8), 205 (100), 105 (8), 77 (2). HRMS $m / z$ calcd for $\mathrm{C}_{34} \mathrm{H}_{40} \mathrm{~N}_{2} \mathrm{O}_{6}[\mathrm{M}+\mathrm{H}]^{+}$572.2886, found 572.2869.

\section{$N$-(1-(3-(allyloxy)phenyl)-1-(benzylaminocarbonyl)methyl)- $N$-phenyl-6-hydroxy-2,5,7,8-}

tetramethylchroman-2-carboxamide (8h). This compound was obtained by method B. The crude product was purified by flash column chromatography (hexane:EtOAc, 7:3) to rendered the desired Ugi product $(\mathbf{8 h})$ as a yellow oil $(40 \%) .{ }^{1} \mathrm{H} \mathrm{NMR}\left(\mathrm{CDCl}_{3}, 400 \mathrm{MHz}\right): \delta 7.40-$ $7.30(\mathrm{~m}, 6 \mathrm{H}), 7.26-7.19(\mathrm{~m}, 8 \mathrm{H}), 7.16-7.03(\mathrm{~m}, 8 \mathrm{H}), 6.76-6.73(\mathrm{~m}, 2 \mathrm{H}), 6.70-6.62(\mathrm{~m}, 2 \mathrm{H})$, $6.59(\mathrm{~s}, 1 \mathrm{H}), 6.53(\mathrm{~s}, 1 \mathrm{H}), 6.48$ (as, 1H), 6.54-6.52(m, 2H), 6.45 (sa, 2H), $6.14(\mathrm{sa}, 1 \mathrm{H}), 5.93-$ $5.83(\mathrm{~m}, 2 \mathrm{H}), 5.46(\mathrm{~s}, 2 \mathrm{H}), 5.33(\mathrm{bs}, 1 \mathrm{H}), 6.01-5.92(\mathrm{~m}, 3 \mathrm{H}), 5.66(\mathrm{~s}, 2 \mathrm{H}), 5.37-5.23(\mathrm{~m}, 4 \mathrm{H})$ 4.53-4.41 (m, 4H), 4.35-4.24 (m, 4H), 2.80-2.50 (m, 6H), $2.12(\mathrm{~s}, 3 \mathrm{H}), 2.09(\mathrm{~s}, 3 \mathrm{H}), 2.05(\mathrm{~s}$, 3H), $2.02(\mathrm{~s}, 3 \mathrm{H}), 1.72(\mathrm{~s}, 3 \mathrm{H}), 1.67(\mathrm{~s}, 3 \mathrm{H}), 1.60-1.51(\mathrm{~m}, 2 \mathrm{H}), 1.27(\mathrm{~s}, 3 \mathrm{H}), 1.23(\mathrm{~s}, 3 \mathrm{H})$.

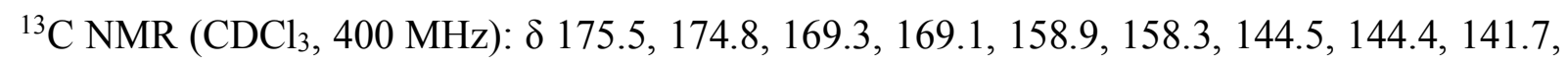
$140.5,138.3,138.1,135.9,135.6,133.1,132.9,129.8,129.3,129.2,129.1,128.6,127.6$, $127.5,127.4,127.3,127.2,125.3,124.8,122.9,122.7,122.6,122.3,119.9,118.9,117.7$, $116.1,115.8,115.3,114.8,80.4,80.2,68.6,43.7,32.6,32.4,27.7,27.6,21.2,21.1,12.1,12.0$ 11.6, 11.5, 11.4. MS (EI, $70 \mathrm{eV}): m / z(\%) 604\left(\mathrm{M}^{+}, 35\right), 373$ (11), 281 (10), 205 (100), 189 (9), 91 (15). HRMS $m / z$ calcd for $\mathrm{C}_{38} \mathrm{H}_{40} \mathrm{~N}_{2} \mathrm{O}_{5}[\mathrm{M}+\mathrm{H}]^{+} 604.2937$, found 604.2919.

\section{$N$-(1-(3-(allyloxy)phenyl)-1-(tert-butylaminocarbonyl)methyl)- $N$-phenyl-6-hydroxy-}

2,5,7,8-tetramethylchroman-2-carboxamide (8i). This compound was obtained by method A or C. The crude product was purified by flash column chromatography (hexane:EtOAc, 7:3) to rendered the desired Ugi product (8i) as a white solid $(37-55 \%)$. mp $66.0-68.0{ }^{\circ} \mathrm{C} .{ }^{1} \mathrm{H}$ 
NMR $\left(\mathrm{CDCl}_{3}, 400 \mathrm{MHz}\right): \delta 7.08-6.93(\mathrm{~m}, 8 \mathrm{H}), 6.82-6.74(\mathrm{~m}, 2 \mathrm{H}), 6.72-6.63(\mathrm{~m}, 2 \mathrm{H}), 6.60-$ $6.58(\mathrm{~m}, 2 \mathrm{H}), 6.54-6.52(\mathrm{~m}, 2 \mathrm{H}), 6.45(\mathrm{sa}, 2 \mathrm{H}), 6.14(\mathrm{sa}, 1 \mathrm{H}), 5.93-5.83(\mathrm{~m}, 2 \mathrm{H}), 5.46(\mathrm{~s}, 2 \mathrm{H})$, $5.33(\mathrm{sa}, 1 \mathrm{H}), 5.29-5.22(\mathrm{~m}, 2 \mathrm{H}), 5.19-5.14(\mathrm{~m}, 2 \mathrm{H}), 4.29-4.22(\mathrm{~m}, 4 \mathrm{H}), 2.70-2.42(\mathrm{~m}, 6 \mathrm{H})$, $2.03(\mathrm{~s}, 3 \mathrm{H}), 2.02(\mathrm{~s}, 3 \mathrm{H}), 1.96(\mathrm{~s}, 3 \mathrm{H}), 1.93(\mathrm{~s}, 3 \mathrm{H}), 1.61(\mathrm{~s}, 3 \mathrm{H}), 1.58(\mathrm{~s}, 3 \mathrm{H}), 1.48-1.41(\mathrm{~m}$, 2H), $1.26(\mathrm{~s}, 9 \mathrm{H}), 1.21(\mathrm{~s}, 9 \mathrm{H}), 1.17(\mathrm{~s}, 3 \mathrm{H}), 1.13(\mathrm{~s}, 3 \mathrm{H}) \cdot{ }^{13} \mathrm{C} \mathrm{NMR}\left(\mathrm{CDCl}_{3}, 100 \mathrm{MHz}\right): \delta$ $175.2,174.7,168.5,168.3,158.3,144.9,144.8,144.5,144.4,141.8,140.5,136.4,136.1$, $133.2,133.1,129.1,129.0,127.9,127.9,127.3,127.1,122.7,122.6,122.5,122.0,120.8$, $120.6,118.1,117.9,117.6,115.9,115.6,115.1,114.6,80.3,80.2,68.6,51.4,51.3,32.5,32.4$, 28.6, 28.5, 27.7, 27.5, 21.9, 12.0, 11.6, 11.5, 11.3. MS (EI, $70 \mathrm{eV}): m / z(\%) 570\left(\mathrm{M}^{+}, 32\right), 497$ (2), 238 (43), 205 (100), 57 (5). HRMS m/z calcd for $\mathrm{C}_{38} \mathrm{H}_{40} \mathrm{~N}_{2} \mathrm{O}_{5}[\mathrm{M}+\mathrm{H}]^{+}$570.3094, found 570.3093 .

\section{$N$-(1-(3-(allyloxy)phenyl)-1-(cyclohexylaminocarbonyl)methyl)- $N$-phenyl-6-hydroxy-}

2,5,7,8-tetramethylchroman-2-carboxamide (8j). This compound was obtained by method

C. The crude product was purified by flash column chromatography (hexane:EtOAc, 7:3) to rendered the desired Ugi product $(\mathbf{8 j})$ as a white solid (32\%). mp 171.0-173.0 ${ }^{\circ} \mathrm{C} .{ }^{1} \mathrm{H}$ NMR $\left(\mathrm{CDCl}_{3}, 400 \mathrm{MHz}\right): \delta$ 7.20-7.04 (m, 10H), 6.95-6.83 (m, 2H), 6.80-6.75 (m, 2H), 6.70-6.68 (m, 1H), 6.64-6.61(m, 2H), $6.54(\mathrm{~s}, 1 \mathrm{H}), 6.20(\mathrm{bs}, 1 \mathrm{H}), 6.05-5.95(\mathrm{~m}, 2 \mathrm{H}), 5.70(\mathrm{~s}, 2 \mathrm{H}), 5.60$ (s, $1 \mathrm{H}), 5.54(\mathrm{bs}, 1 \mathrm{H}), 5.40-5.34(\mathrm{~m}, 2 \mathrm{H}), 5.30-5.26(\mathrm{~m}, 2 \mathrm{H}), 4.40-4.30(\mathrm{~m}, 4 \mathrm{H}), 3.87-3.78(\mathrm{~m}$, 2H), 2.83-2.53 (m, 6H), $2.14(\mathrm{~s}, 6 \mathrm{H}), 2.08(\mathrm{~s}, 3 \mathrm{H}), 2.04(\mathrm{~s}, 3 \mathrm{H}), 1.95-1.85(\mathrm{~m}, 4 \mathrm{H}), 1.73$ (s, 3H), $1.69(\mathrm{~s}, 3 \mathrm{H}), 1.64-1.52(\mathrm{~m}, 6 \mathrm{H}), 1.42-1.33(\mathrm{~m}, 5 \mathrm{H}), 1.33(\mathrm{~s}, 3 \mathrm{H}), 1.24(\mathrm{~s}, 3 \mathrm{H}), 1.17-1.08$ (m, 5H), 1.00-0.88 (s, 2H). ${ }^{13} \mathrm{C} \mathrm{NMR}\left(\mathrm{CDCl}_{3}, 100 \mathrm{MHz}\right): \delta 175.4,174.8,168.3,168.2,158.3$, $145.0,144.8,144.5,141.8,140.4,136.3,136.0,133.2,133.1,129.1,127.3,127.1,122.9$, $122.6,122.2,120.8,120.6,118.1,118.0,117.9,117.6,116.1,115.7,115.3,114.8,80.4,80.2$, $68.8,48.6,48.4,32.9,32.8,32.6,32.4,27.7,27.6,25.5,24.8,24.7,21.2,12.1,12.0,11.7$, 
11.6, 11.4, 11.3. MS (EI, $70 \mathrm{eV}): m / z(\%) 596\left(\mathrm{M}^{+}, 38\right), 497$ (2), 392 (1), 273 (18), 205(100), 83 (5). HRMS $m / z$ calcd for $\mathrm{C}_{37} \mathrm{H}_{44} \mathrm{~N}_{2} \mathrm{O}_{5}[\mathrm{M}+\mathrm{H}]^{+}$596.3250, found 596.3221 .

\section{$N$-(1-(3-butenyl)-1-(tert-butylaminocarbonyl)methyl)- $N$-phenyl-6-hydroxy-2,5,7,8-}

tetramethylchroman-2-carboxamide (8k). This compound was obtained by method $\mathrm{C}$. The crude product was purified by flash column chromatography (hexane:EtOAc, 85:15) to rendered the desired Ugi product $(\mathbf{8 k})$ as a yellow oil $(51 \%) .{ }^{1} \mathrm{H} \mathrm{NMR}\left(\mathrm{CDCl}_{3}, 400 \mathrm{MHz}\right): \delta$ 7.30-6.97 (m, 10H), $6.66(\mathrm{bs}, 1 \mathrm{H}), 6.55(\mathrm{bs}, 1 \mathrm{H}), 5.57-5.62(\mathrm{~m}, 2 \mathrm{H}), 5.08-4.85(\mathrm{~m}, 6 \mathrm{H}), 2.78-$ $2.53(\mathrm{~m}, 6 \mathrm{H}), 2.11(\mathrm{~s}, 3 \mathrm{H}), 2.09(\mathrm{~s}, 6 \mathrm{H}), 2.04(\mathrm{~s}, 3 \mathrm{H}), 1.97-1.84(\mathrm{~m}, 4 \mathrm{H}), 1.69(\mathrm{~s}, 3 \mathrm{H}), 1.65(\mathrm{~s}$, $3 \mathrm{H}), 1.58-1.41(\mathrm{~m}, 6 \mathrm{H}), 1.35(\mathrm{~s}, 9 \mathrm{H}), 1.31(\mathrm{~s}, 9 \mathrm{H}), 1.28(\mathrm{~s}, 3 \mathrm{H}), 1.24(\mathrm{~s}, 3 \mathrm{H}) .{ }^{13} \mathrm{C} \mathrm{NMR}$ $\left(\mathrm{CDCl}_{3}, 100 \mathrm{MHz}\right): \delta 176.5,176.6,169.5,169.0,145.0,144.4,144.3,139.4,138.1,137.5$, $135.1,130.6,129.0,128.5,128.3,127.9,127.7,127.2,122.7,120.9,120.8,119.6,118.2$, $117.9,117.7,117.4,115.4,115.2,80.5,80.1,60.3,53.4,51.1,50.9,34.7,34.0,32.7,32.6$, $30.5,30.1,28.7,28.6,28.5,27.1,21.4,12.1,12.0,11.7,11.6,11.4,11.3$. MS (EI, $70 \mathrm{eV}): \mathrm{m} / \mathrm{z}$ (\%) $492\left(\mathrm{M}^{+}, 20\right), 325$ (10), 287 (4), 205 (100), 160 (21), 77 (8), 57 (53). HRMS $m / z$ calcd for $\mathrm{C}_{30} \mathrm{H}_{40} \mathrm{~N}_{2} \mathrm{O}_{4}[\mathrm{M}+\mathrm{H}]^{+}$492.2988, found 492.2981.

\section{$N$-(1-(3-butenyl)-1-(tert-butylaminocarbonyl)methyl)- $N$-phenyl-6-tert-}

butoxycarbonyloxy-2,5,7,8-tetramethylchroman-2-carboxamide (81). This compound was obtained by method C. The crude product was purified by flash column chromatography (hexane:EtOAc, 7:3) to rendered the desired Ugi product (8I) as a yellow oil (99\%). ${ }^{1} \mathrm{H}$ NMR $\left(\mathrm{CDCl}_{3}, 400 \mathrm{MHz}\right): \delta 7.17-6.76(\mathrm{~m}, 10 \mathrm{H}), 6.52(\mathrm{bs}, 1 \mathrm{H}), 6.40(\mathrm{bs}, 1 \mathrm{H}), 5.65-5.55(\mathrm{~m}, 2 \mathrm{H})$, 4.88-4.82 (m, 6H), 2.70-2.44 (m, 6H), $1.95(\mathrm{~s}, 3 \mathrm{H}), 1.93(\mathrm{~s}, 3 \mathrm{H}), 1.91(\mathrm{~s}, 3 \mathrm{H}), 1.85(\mathrm{~s}, 3 \mathrm{H})$, 1.83-1.73 (m, 4H), $1.61(\mathrm{~s}, 3 \mathrm{H}), 1.56(\mathrm{~s}, 3 \mathrm{H}), 1.48(\mathrm{~s}, 9 \mathrm{H}), 1.47(\mathrm{~s}, 9 \mathrm{H}), 1.45-1.34(\mathrm{~m}, 6 \mathrm{H})$, $1.26(\mathrm{~s}, 9 \mathrm{H}), 1.23(\mathrm{~s}, 3 \mathrm{H}), 1.22(\mathrm{~s}, 9 \mathrm{H}), 1.16(\mathrm{~s}, 3 \mathrm{H}) .{ }^{13} \mathrm{C} \mathrm{NMR}\left(\mathrm{CDCl}_{3}, 400 \mathrm{MHz}\right): \delta 175.3$, $169.4,169.0,148.2,148.0,141.4,139.2,138.0,137.5,129.3,129.2,128.7,128.4,128.0$, $127.7,127.0,124.7,123.1,117.9,117.6,115.4,113.7,82.6,80.9,80.6,60.4,50.9,32.5,32.3$, 
$30.5,30.2,29.4,28.7,28.6,27.9,27.7,27.5,22.8,21.3,12.6,12.5,11.9,11.8,11.7,11.6 . \mathrm{MS}$

(EI, $70 \mathrm{eV}): m / z(\%) 592\left(\mathrm{M}^{+}, 9\right), 492$ (36), 305 (3), 205 (96), 160 (100), 77 (10), 57 (49).

HRMS $m / z$ calcd for $\mathrm{C}_{35} \mathrm{H}_{48} \mathrm{~N}_{2} \mathrm{O}_{6}[\mathrm{M}+\mathrm{H}]^{+}$592.3512, found 592.3491.

\section{$N$-(1-(3-(3-nitrooxipropoxy)phenyl)-1-(phenethylaminocarbonyl)methyl)- $N$-phenyl-6-}

hydroxy-2,5,7,8-tetramethylchroman-2-carboxamide $(\mathbf{8 m})$. This compound was obtained by method C. The crude product was purified by flash column chromatography (hexane:EtOAc, $7: 3)$ to rendered the desired Ugi product $(\mathbf{8 m})$ as a yellow oil $(29 \%) .{ }^{1} \mathrm{H}$ NMR $\left(\mathrm{CDCl}_{3}, 400 \mathrm{MHz}\right): \delta$ 7.28-7.14 (m,12H), 7.07-7.03 (m, 6H), 6.74-6.70 (m,4H), 6.61$6.59(\mathrm{~m}, 2 \mathrm{H}), 6.48(\mathrm{~s}, 2 \mathrm{H}), 6.12(\mathrm{sa}, 1 \mathrm{H}), 5.65(\mathrm{sa}, 1 \mathrm{H}), 5.61(\mathrm{~s}, 1 \mathrm{H}), 5.50(\mathrm{~s}, 1 \mathrm{H}), 4.64-4.60$ (m, 4H), 3.90-3.74 (m, 4H), 3.60-3.40 (m, 4H), 2.85-2.71 (m, 6H), 2.70-2.52 (m, 4H), 2.14$2.11(\mathrm{~m}, 4 \mathrm{H}), 2.13(\mathrm{~s}, 6 \mathrm{H}), 2.07(\mathrm{~s}, 3 \mathrm{H}), 2.03(\mathrm{~s}, 3 \mathrm{H}), 1.70(\mathrm{~s}, 3 \mathrm{H}), 1.65(\mathrm{~s}, 3 \mathrm{H}), 1.58-1.51$ $(\mathrm{m}, 2 \mathrm{H}), 1.27(\mathrm{~s}, 3 \mathrm{H}), 1.23(\mathrm{~s}, 3 \mathrm{H}) .{ }^{13} \mathrm{C} \mathrm{NMR}\left(\mathrm{CDCl}_{3}, 100 \mathrm{MHz}\right): \delta 175.5,174.8,169.2$, $169.0,158.2,158.1,144.4,141.6,138.8,136.2,135.9,129.34,129.2,128.8,128.5,128.4$, $128.0,127.3,127.2,126.4,126.3,123.1,122.7,115.8,115.7,115.0,114.4,80.3,80.2,69.9$, $69.8,41.0,40.8,35.5,35.4,27.7,27.6,26.8,21.2,21.1,12.1,12.0,11.7,11.6,11.4,11.3 . \mathrm{MS}$ (EI, $70 \mathrm{eV}): m / z(\%) 681\left(\mathrm{M}^{+}, 4\right), 636(23), 578$ (4), 324 (5), $256(34), 205$ (100). HRMS m/z calcd for $\mathrm{C}_{39} \mathrm{H}_{43} \mathrm{~N}_{3} \mathrm{O}_{8}[\mathrm{M}+\mathrm{H}]^{+}$681.3050, found 681.3018 .

\section{$N$-(1-(tert-butylaminocarbonyl)-1-(3-(3-nitrooxypropoxy)phenyl)methyl)- $N$-phenyl-6-}

hydroxy-2,5,7,8-tetramethylchroman-2-carboxamide (8n). This compound was obtained by method C. The crude product was purified by flash column chromatography (hexane:EtOAc gradient) to rendered the desired Ugi product $(\mathbf{8 n})$ as a yellow oil $(25 \%) .{ }^{1} \mathrm{H}$ NMR $\left(\mathrm{CDCl}_{3}, 400 \mathrm{MHz}\right): \delta$ 7.19-7.01 (m, 8H), 6.96-6.86 (m, 2H), 6.74-6.64 (m,6H), 6.59 $(\mathrm{s}, 1 \mathrm{H}), 6.50(\mathrm{~s}, 1 \mathrm{H}), 5.64(\mathrm{~s}, 1 \mathrm{H}), 5.58(\mathrm{~s}, 1 \mathrm{H}), 4.65-4.60(\mathrm{~m}, 4 \mathrm{H}), 3.96-3.76(\mathrm{~m}, 4 \mathrm{H}), 2.80-$ $2.52(\mathrm{~m}, 6 \mathrm{H}), 2.27-2.14(\mathrm{~m}, 4 \mathrm{H}), 2.12(\mathrm{~s}, 6 \mathrm{H}), 2.07(\mathrm{~s}, 3 \mathrm{H}), 2.06(\mathrm{~s}, 3 \mathrm{H}), 1.71(\mathrm{~s}, 3 \mathrm{H}), 1.67$ $(\mathrm{s}, 3 \mathrm{H}), 1.58-1.50(\mathrm{~m}, 2 \mathrm{H}), 1.35(\mathrm{~s}, 9 \mathrm{H}), 1.31(\mathrm{~s}, 9 \mathrm{H}), 1.26(\mathrm{~s}, 3 \mathrm{H}), 1.22(\mathrm{~s}, 3 \mathrm{H}) .{ }^{13} \mathrm{C} \mathrm{NMR}$ 
$\left(\mathrm{CDCl}_{3}, 100 \mathrm{MHz}\right): \delta 175.3,168.5,168.4,158.0,144.4,136.4,129.1,127.9,127.4,127.1$, 123.0, 122.6, 122.4, 120.8, 115.7, 115.4, 114.8, 114.3, 80.3, 80.2, 69.2, 63.3, 51.4, 51.3, 28.6, 27.7, 27.6, 26.9, 26.8, 21.2, 12.1, 12.0, 11.6, 11.5, 11.4, 11.5. MS (EI, $70 \mathrm{eV}): \mathrm{m} / z(\%) 633$ $\left(\mathrm{M}^{+}, 16\right), 588(8), 486(5), 324$ (3), $256(20), 205$ (100). HRMS $m / z$ calcd for $\mathrm{C}_{35} \mathrm{H}_{43} \mathrm{~N}_{3} \mathrm{O}_{8}$ $[\mathrm{M}+\mathrm{H}]^{+}$633.3134, found 633.3122.

\section{$N$-(1-(tert-butylaminocarbonyl)-1-(3-(4-nitrooxybutoxy)phenyl)methyl)- $N$-phenyl-6-} methoxy-2,5,7,8-tetramethylchroman-2-carboxamide (80). This compound was obtained by method B. The crude product was purified by flash column chromatography (hexane:EtOAc, 95:5) to rendered the desired Ugi product $(\mathbf{8 0})$ as a yellow oil $(23 \%)$ and Passerini product (7k) as a yellow oil (7\%). 8o: ${ }^{1} \mathrm{H}$ NMR $\left(\mathrm{CDCl}_{3}, 400 \mathrm{MHz}\right): \delta 7.17-7.02$ (7H), 6.97-6.77 (m, 3H), 6.73-6.67 (m, 5H), $6.63(\mathrm{~d}, J=8.0 \mathrm{~Hz}, 1 \mathrm{H}), 6.59(\mathrm{~s}, 1 \mathrm{H}), 6.50(\mathrm{~s}$, 1H), $6.25(\mathrm{~s}, \mathrm{NH}, 1 \mathrm{H}), 5.60(\mathrm{~s}, \mathrm{NH}, 1 \mathrm{H}), 5.57(\mathrm{~s}, 1 \mathrm{H}), 5.47(\mathrm{~s}, 1 \mathrm{H}), 4.51(\mathrm{~m}, 4 \mathrm{H}), 3.79(\mathrm{~m}$, 4H), $3.65(\mathrm{~s}, 3 \mathrm{H}), 3.62(\mathrm{~s}, 3 \mathrm{H}), 2.80-2.51(\mathrm{~m}, 6 \mathrm{H}), 2.16(\mathrm{~s}, 3 \mathrm{H}), 2.15(\mathrm{~s}, 3 \mathrm{H}), 2.07(\mathrm{~s}, 3 \mathrm{H})$, $2.04(\mathrm{~s}, 3 \mathrm{H}), 1.94-1.80(\mathrm{~m}, 8 \mathrm{H}), 1.70(\mathrm{~s}, 3 \mathrm{H}), 1.68(\mathrm{~s}, 3 \mathrm{H}), 1.55(\mathrm{~m}, 2 \mathrm{H}), 1.35(\mathrm{~s}, 9 \mathrm{H}), 1.31(\mathrm{~s}$, 9H), $1.25(\mathrm{~s}, 3 \mathrm{H}), 1.22(\mathrm{~s}, 2 \mathrm{H}) .{ }^{13} \mathrm{C} \mathrm{NMR}\left(\mathrm{CDCl}_{3}, 100 \mathrm{MHz}\right): \delta 175.0,168.5,158.4,148.2$, $146.7,146.6,136.3,129.1,127.8,127.5,127.3,127.1,123.0,122.1,118.5,115.6,114.8$, $114.3,80.7,72.9,71.0,69.2,66.7,60.4,51.4,32.4,28.6,27.7,25.4,23.8,21.1,12.4,11.7$, 11.5. MS (EI, $70 \mathrm{eV}): m / z(\%) 661\left(\mathrm{M}^{+}, 17\right), 586(3), 416(5), 315$ (21), 219 (100), 57 (10).

\section{$N-(1-(3-(3-n i t r o o x y p r o p o x y) p h e n y l)-1-(N-$}

(ethyloxycarbonylmethyl)aminocarbonyl)methyl)- $N$-phenyl-6-hydroxy-2,5,7,8-

tetramethylchroman-2-carboxamide (8p). This compound was obtained by method B. The crude product was purified by flash column chromatography (hexane:EtOAc, 8:2) to rendered the desired Ugi product (8p) as a pink solid (35\%). mp 56.0-58.0 ${ }^{\circ} \mathrm{C} .{ }^{1} \mathrm{H}$ NMR $\left(\mathrm{CDCl}_{3}, 400\right.$ MHz): $\delta$ 7.19-7.07 (m, 8H), 6.95-6,84 (m, 2H), 6.75-6.68 (m, 4H), $6.62(\mathrm{sa}, 1 \mathrm{H}), 6.61(\mathrm{~s}$, $1 \mathrm{H}), 6.52(\mathrm{~s}, 1 \mathrm{H}), 6.20(\mathrm{sa}, 1 \mathrm{H}), 5.73(\mathrm{~s}, 1 \mathrm{H}), 5.71(\mathrm{~s}, 1 \mathrm{H}), 4.64-4.60(\mathrm{~m}, 4 \mathrm{H}), 4.23-4.11(\mathrm{~m}$, 
6H), 4.09-4.03 (m, 2H), 3.98-3.76 (m, 4H), 2.78-2.50 (m, 6H), 2.15-2.10 (m, 10H), 2.07 (s, $6 \mathrm{H}), 2.02(\mathrm{~s}, 3 \mathrm{H}), 1.71(\mathrm{~s}, 3 \mathrm{H}), 1.69(\mathrm{~s}, 1 \mathrm{H}), 1.60-1.52(\mathrm{~m}, 2 \mathrm{H}), 1.31-1.23(\mathrm{~m}, 12 \mathrm{H}) .{ }^{13} \mathrm{C}$ $\mathrm{NMR}\left(\mathrm{CDCl}_{3}, 100 \mathrm{MHz}\right): \delta 175.9,174.9,169.6,169.2,158.2,135.8,135.4,129.3,129.2$, $128.0,127.4,123.4,122.7,116.0,115.6,115.3,114.7,80.4,80.2,70.0,69.9,63.3,61.4,41.6$, $41.5,32.8,32.4,27.7,26.9,21.2,21.1,14.1,12.1,12.0,11.7,11.3$. MS (EI, $70 \mathrm{eV}): m / z(\%)$ $663\left(\mathrm{M}^{+}, 7\right), 618$ (12), 324 (5), 256 (16), 205 (100). HRMS m/z calcd for $\mathrm{C}_{35} \mathrm{H}_{41} \mathrm{~N}_{3} \mathrm{O}_{10}$ $[\mathrm{M}+\mathrm{H}]^{+}$663.2792, found 663.2828 .

\section{$N$-(1-(3-(3-phenylsulfonyl-1,2,5-oxadiazole}

$\mathrm{N}^{2}$-oxide-4-yl)phenoxy)-1-(tert-

butylaminocarbonyl)methyl)- $N$-phenyl-6-hydroxy-2,5,7,8-tetramethylchroman-2-

carboxamide (8q). This compound was obtained by method A. The crude product was purified by flash column chromatography (hexane:EtOAc gradient) to rendered the desired Ugi product $(\mathbf{8 q})$ as a yellow solid $(25 \%)$. mp 68.0-70.0 ${ }^{\circ} \mathrm{C} .{ }^{1} \mathrm{H} \mathrm{NMR}\left(\mathrm{CDCl}_{3}, 400 \mathrm{MHz}\right)$ : $\delta$ 8.12-8.10 (m, 4H), 7.84-7.75 (m, 2H), 7.69-7.65 (m, 3H), 7.57-7.47 (m, 2H), 7.41-7.33 (m, 2H), 7.24-7.20 (m, 3H), 7.17-6.99 (m, 12H), 6.33 (sa, 1H), $5.78(\mathrm{sa}, 1 \mathrm{H}), 5.64-5.58(\mathrm{~m}, 2 \mathrm{H})$, 2.79-2.50 (m, 6H), 2.12-2.03 (m, 12H), $1.69(\mathrm{~s}, 3 \mathrm{H}), 1.67(\mathrm{~s}, 3 \mathrm{H}), 1.58-1.51(\mathrm{~m}, 2 \mathrm{H}), 1.35$ (s, 9H), $1.30(\mathrm{~s}, 9 \mathrm{H}), 1.28(\mathrm{~s}, 3 \mathrm{H}), 1.26(\mathrm{~s}, 3 \mathrm{H}) .{ }^{13} \mathrm{C}-\mathrm{NMR}\left(\mathrm{CDCl}_{3}, 100 \mathrm{MHz}\right): \delta 175.7,175.6$, $172.11,167.8,167.6,162.3,159.0,158.2,152.14,144.9,144.4,141.2,137.8,137.3,135.9$, $129.8,129.6,129.5,129.1,128.7,128.5,128.4,128.1,127.6,127.5,125.3,124.8,122.6$, $121.7,121.5,119.9,119.4,118.9,80.3,80.1,68.4,32.6,32.5,28.6,28.5,27.7,27.6,21.2$, 21.1, 12.1, 12.0, 11.7, 11.6, 11.4. MS (EI, $70 \mathrm{eV}): m / z(\%) 754\left(\mathrm{M}^{+}, 2\right), 739(1), 529(24), 456$ (20), 428 (19), 231 (24), 205 (63). HRMS m/z calcd for $\mathrm{C}_{40} \mathrm{H}_{42} \mathrm{~N}_{4} \mathrm{O}_{9} \mathrm{~S}[\mathrm{M}+\mathrm{H}]^{+} 754.2726$, found 754.2713 . 
purified by flash column chromatography (hexane:EtOAc, 6:4) to rendered the desired Ugi product (8r) as a white solid (8 \%). mp 73.0-75.0 ${ }^{\circ} \mathrm{C} .{ }^{1} \mathrm{H}$ NMR $\left(\mathrm{CDCl}_{3}, 400 \mathrm{MHz}\right): \delta 8.13-$ $8.10(\mathrm{~m}, 4 \mathrm{H}), 7.84-7.80(\mathrm{~m}, 2 \mathrm{H}), 7.70-7.66(\mathrm{~m}, 4 \mathrm{H}), 7.31-7.13(\mathrm{~m}, 20 \mathrm{H}), 7.07-6.97(\mathrm{~m}, 8 \mathrm{H})$, $6.19(\mathrm{sa}, 1 \mathrm{H}), 5.76-5.74(\mathrm{~m}, 2 \mathrm{H}), 5.53(\mathrm{~s}, 1 \mathrm{H}), 3.63-3.44(\mathrm{~m}, 4 \mathrm{H}), 2.82-2.49(\mathrm{~m}, 10 \mathrm{H}), 2.12-$ $2.03(\mathrm{~m}, 12 \mathrm{H}), 1.67(\mathrm{~s}, 3 \mathrm{H}), 1.65(\mathrm{~s}, 3 \mathrm{H}), 1.58-1.51(\mathrm{~m}, 2 \mathrm{H}), 1.30(\mathrm{~s}, 3 \mathrm{H}), 1.26(\mathrm{~s}, 3 \mathrm{H}) .{ }^{13} \mathrm{C}$ NMR $\left(\mathrm{CDCl}_{3}, 100 \mathrm{MHz}\right): \delta 176.1,175.2,168.7,168.3,153.2,152.1,145.1,144.9$, $144.5,144.4,141.0,140.5,138.7,138.6,137.8,137.2,137.0,135.9,134.3,134.1,129.8$, $129.7,129.5,129.1,129.0,128.8,128.7,128.6,128.5,128.4,128.3,127.5,126.5,126.4$, $122.6,121.8,121.7,121.2,120.8,119.8,119.4,80.3,80.2,68.6,41.4,41.0,35.4,35.3,32.8$, 32.4, 27.7, 27.6, 21.2, 21.1, 21.0, 20.7, 12.1, 12.0, 11.7, 11.6, 11.4, 11.3. MS (EI, $70 \mathrm{eV}): \mathrm{m} / \mathrm{z}$ (\%) $802\left(\mathrm{M}^{+}, 2\right), 577$ (6), 487 (4), 428 (6), 373 (5), 338 (18), 205 (97), 141 (16), 105 (38), 77 (100). HRMS $m / z$ calcd for $\mathrm{C}_{44} \mathrm{H}_{42} \mathrm{~N}_{4} \mathrm{O}_{9} \mathrm{~S}[\mathrm{M}+\mathrm{H}]^{+} 802.2731$, found 802.2720.

\section{$N-\left(1-\left(3-\left(3-(p h e n y l s u l f o n y l)-1,2,5-0 x a d i a z o l e \quad \quad \quad N^{2}\right.\right.\right.$-oxide $\left.\left.\quad-4-y l\right) p h e n o x y\right)-1-((N-$} ethyloxycarbonylmethyl)aminocarbonyl)methyl)-N-phenyl-6-hydroxy-2,5,7,8-

tetramethylchroman-2-carboxamide (8s). This compound was obtained by method A. The crude product was purified by flash column chromatography (hexane:EtOAc, 6:4) to rendered the desired Ugi product (8s) as a yellow oil which crystallized on cooling (38\%). ${ }^{1} \mathrm{H}$ NMR $\left(\mathrm{CDCl}_{3}, 400 \mathrm{MHz}\right): \delta 8.10-8.08(\mathrm{~m}, 4 \mathrm{H}), 7.83-7.77(\mathrm{~m}, 2 \mathrm{H}), 7.69-7.65(\mathrm{~m}, 4 \mathrm{H}), 7.24-7.09$ (m, 10H), 7.03-6.89 (m, 6H), 6.88-6.86 (m, 2H), $6.67(\mathrm{sa}, 1 \mathrm{H}), 6.36(\mathrm{sa}, 1 \mathrm{H}), 5.88(\mathrm{~s}, 1 \mathrm{H})$, $5.78(\mathrm{~s}, 1 \mathrm{H}), 4.24-4.01(\mathrm{~m}, 8 \mathrm{H}), 2.76-2.49(\mathrm{~m}, 6 \mathrm{H}), 2.15-2.02(\mathrm{~m}, 12 \mathrm{H}), 1.69(\mathrm{~s}, 3 \mathrm{H}), 1.68(\mathrm{~s}$, $3 \mathrm{H}), 1.59-1.53(\mathrm{~m}, 2 \mathrm{H}), 1.31-1.21(\mathrm{~m}, 12 \mathrm{H}) .{ }^{13} \mathrm{C} \mathrm{NMR}\left(\mathrm{CDCl}_{3}, 100 \mathrm{MHz}\right): \delta 176.5,175.4$, $169.1,168.6,158.3,152.4,144.5,144.3,137.8,136.9,136.5,135.8,129.7,129.5,129.1$, $129.0,128.7,128.6,128.5,128.2,127.6,122.6,121.9,121.3,120.7,119.9,119.4,80.3,80.2$, 68.0, 41.6, 41.4, 32.9, 32.4, 27.8, 27.7, 21.2, 21.1, 12.2, 12.0, 11.8, 11.6, 11.3. MS (EI, 70 
eV): $m / z(\%) 784\left(\mathrm{M}^{+}, 1\right), 768(1), 560$ (16), 225 (3), 205 (100), 77 (63). HRMS m/z calcd for $\mathrm{C}_{40} \mathrm{H}_{40} \mathrm{~N}_{4} \mathrm{O}_{11} \mathrm{~S}[\mathrm{M}+\mathrm{H}]^{+}$784.2415, found: 784.2403.

\subsection{Cell lines and growth conditions}

Human breast cancer cell line T-47D (ATCC, HTB-133) was grown in RPMI 1640 supplemented with $10 \%(\mathrm{v} / \mathrm{v})$ heat inactivated FCS. The THP-1 human monocyte-like cells (ATCC TIB-202, USA) were maintained in RPMI 1640, GlutaMAX supplemented with 10\% FBS, $0.05 \mathrm{mM} \beta$-mercaptoethanol, $100 \mu \mathrm{g} / \mathrm{L}$ streptomycin and $100 \mathrm{IU} / \mathrm{mL}$ penicillin. The human solid tumor cell lines HBL-100, HeLa, SW1573, and WiDr were a kind gift from Prof. G. J. Peters (VU Medical Center, Amsterdam, The Netherlands). Cells were cultured in RPMI 1640 supplemented with 5\% heat inactivated FCS and $2 \mathrm{mM} \mathrm{L-glutamine.}$

All cells were routinely propagated in $25 \mathrm{~cm}^{2}$ tissue culture flasks at $37{ }^{\circ} \mathrm{C}, 5 \% \mathrm{CO}_{2}, 95 \%$ humidified air incubator until reaching approximately $70 \%$ confluence. Cells were subsequently trypsinized, concentration was adjusted, and used for different experimental settings. For all described assays cells were cultured for less than twenty passages.

\subsection{Antiproliferative activity}

All the synthesized compounds were screened for antiproliferative activity against HBL-100, HeLa, SW1573, T-47D and WiDr cell lines using the SRB assay [43]. Exponentially growing cells were trypsinized and resuspended in antibiotic containing medium (100 units penicillin $\mathrm{G}$ and $0.1 \mathrm{mg}$ of streptomycin per $\mathrm{mL}$ ). Single cell suspensions displaying $>97 \%$ viability determined by trypan blue dye exclusion were subsequently counted. After counting, dilutions were made to give the appropriate cell densities for inoculation onto 96-well microtiter plates. Cells were inoculated in a final volume of $100 \mathrm{~mL}$ per well at densities of 10000 (HBL-100, HeLa and SW1573), 15000 (T-47D), and 20000 (WiDr) cells per well, based on their doubling times. Compounds were initially dissolved in DMSO at 400 times the desired final 
maximum test concentration. Control cells were exposed to an equivalent concentration of DMSO $(0.25 \% \mathrm{v} / \mathrm{v}$, negative control). Each agent was tested in triplicate at different dilutions in the range of 1 to $100 \mu \mathrm{M}$. The drug treatment started on day 1 after plating. Drug incubation times were $48 \mathrm{~h}$, after which cells were precipitated with $25 \mathrm{~mL}$ ice-cold TCA $(50 \% \mathrm{w} / \mathrm{v})$ and fixed for $60 \mathrm{~min}$ at $4{ }^{\circ} \mathrm{C}$. Then the SRB assay was performed [43]. The optical density (OD) of each well was measured at $492 \mathrm{~nm}$, using BioTek's PowerWave XS Absorbance Microplate Reader. Values were corrected for background OD from wells only containing medium. Standard anticancer drugs cis-platin and etoposide were used as positive controls.4.5 MTT assay for testing macrophage cytotoxicity

THP-1 cells were seeded $\left(1\right.$ X $10^{5}$ cells/well) in 96-well microplates with $100 \mu \mathrm{L}$ of RPMI medium supplemented with fetal serum and phorbol ester was added to the culture medium $(200 \mathrm{nM})$ to induce macrophage differentiation. Cells were allowed to attach for $48 \mathrm{~h}$ in a humidified $5 \% \mathrm{CO}_{2}, 95 \%$ air atmosphere at $37{ }^{\circ} \mathrm{C}$ and, then, exposed to hybrid compounds (1$100 \mu \mathrm{M})$ for $48 \mathrm{~h}$. Afterwards, cell viability was assessed by measuring the mitochondrialdependent reduction of MTT to formazan. For that purpose, MTT was added to cells to a final concentration of $0.5 \mathrm{mg} / \mathrm{mL}$ and cells were incubated at $37^{\circ} \mathrm{C}$ for $1 \mathrm{~h}$.

After removing the media, formazan crystals were dissolved in isopropanol, and the absorbance at $570 \mathrm{~nm}$ was read using a microplate spectrophotometer. Results are expressed as $\mathrm{EC}_{50}$ (compound concentration that reduced $50 \%$ control absorbance at $570 \mathrm{~nm}$ ). Every $\mathrm{EC}_{50}$ is the average of at least four determinations.

\subsection{Apoptosis assay}

T-47D and THP-1 cells were used for apoptosis studies. Cells in early and late stages of apoptosis were detected by Annexin V-FITC and Propidium Iodide (PI) staining. Cells were seeded in 12 well plates $(100000$ cell/well) and cultured for 24 h. The $7 \mathbf{h}, \mathbf{8 i}, \mathbf{8 n}$ and $\mathbf{8 q}$ 
compounds were added to a final concentration of $4.2 ; 3.5 ; 4.6$; and $5.3 \mu \mathrm{M}$, respectively in serum-free medium and cells were further incubated at $37{ }^{\circ} \mathrm{C}$ for $24 \mathrm{~h}(0.1 \%(\mathrm{v} / \mathrm{v}) \mathrm{DMSO}$ served as vehicle control). Supernatant containing cells and trypsinized cells were collected, wash once with PBS and resuspended in Annexin V buffer (25 mM HEPES, $140 \mathrm{mM} \mathrm{NaCl}, 1$ $\mathrm{mM}$ EDTA, $\mathrm{pH} 7.4,0.1 \%$ (v/v) bovine serum albumin). For $100 \mu \mathrm{L}$ of cell suspension, $2.5 \mu \mathrm{L}$ of Annexin V-FITC were added and incubated for 15 min at room temperature. Finally, $2 \mu \mathrm{L}$ PI $(250 \mu \mathrm{g} / \mathrm{mL})$ were added prior to analysis. Samples were acquired in a Cyan ADP Analyzer (Beckman Coulter, USA) equipped with $488 \mathrm{~nm}$ laser. Fluorescence emissions were detected using band-pass filters 530/40 and 613/20. For each sample, 10000 counts gated on a forward scatter (FSC) versus side scatter (SSC) dot plot, excluding doublets were recorded. Summit v4.3 software was used for data acquisition and FlowJovX.0.7 for data analysis. Fold change was calculated as the ratio between the percentage of Annexin $\mathrm{V}$ positive cells for the treated sample and the untreated control.

\subsection{Cell cycle analysis}

For cell cycle analysis cells were grown in a $25 \mathrm{~cm}^{2}$ tissue culture flask. DNA content in G1/G0, S, G2/M phases of cell cycle was analyzed using flow cytometry. Cells were seeded (400000 cell/mL) in $25 \mathrm{~cm}^{2}$ tissue culture flasks, cultured during $24 \mathrm{~h}$ and then treated with $\mathbf{8 i}$ compound at $3.5 \mu \mathrm{M}$ for $48 \mathrm{~h}$. Then, cells were harvested, washed with PBS, fixed and permeabilized with $70 \%$ ice-cold ethanol for more than $2 \mathrm{~h}$. Subsequently, the cells were resuspended in a freshly staining buffer (final concentration of $50 \mu \mathrm{g} / \mathrm{mL}$ of PI and $50 \mu \mathrm{g} / \mathrm{mL}$ DNase-free RNase prepared in PBS containing 2 mM EDTA) and incubated for 30 min at 37 ${ }^{\circ} \mathrm{C}$. Cell cycle distribution analysis was performed in a CyAn ${ }^{\mathrm{TM}} \mathrm{ADP}$ flow cytometer using Summit v4.3 software for data acquisition. For each sample, cellular aggregates were gating out and at least 10000 cells were counted and plotted on a single parameter histogram. The 
percentage of cells in the $G_{0} / G_{1}, S, G_{2} / M$ phases and sub- $G_{1}$ peak was then calculated by FlowJo 7.6 software (using the Watson model).

\section{Acknowledgements}

This work was supported by Agencia Nacional de Investigación e Innovación (ANII-Fondo Clemente Estable, FCE-2-2011-1-5717), PEDECIBA-Química, Uruguay and Institut Pasteur de Montevideo - FOCEM Mercosur (COF 03/11). We thank ANII for the scholarship to M.I.

\section{Supplementary data}

Supplementary data Supplementary data associated with this article can be found, in the online version, at http://dx.doi.org/......

\section{References}

[1] J.A.van Diepen, J.F.P. Berbée, L.M. Havekes, P.C.N. Rensen, Atherosclerosis 228 (2013) $306-315$

[2] S. Emami, S. Dadashpour, Eur. J. Med. Chem. 102 (2015) 611-630.

[3] J.S. Ross, N.E. Stagliano, M.J. Donovan, R.E. Breitbart, G.S. Ginsburg, Am. J. Clin. Pathol. 116 (2001) S97-107.

[4] J.S. Ross; N.E. Stagliano, M.J. Donovan, R.E. Breitbart, G.S. Ginsburg, Ann N Y Acad Sci 947 (2001) 271-292.

[5] E. Saita, K. Kondo, Y. Momiyama, Clin Med Insights Cardiol 8 (2015) 61-65.

[6] P. Mathur, Z. Ding, T. Saldeen, J.L. Mehta, Clin Cardiol 38 (2015) 570-576.

[7] F. Galli, A.M. Stabile, M. Betti, C. Conte, A. Pistilli, M. Rende, A. Floridi, A. Azzid, Arch. Biochem. Biophys. 423 (2004) 97-102. 
[8] S. Morley, V. Thakur, D. Danielpour, R. Parker, H. Arai, J. Atkinson, J. Barnholtz-Sloan, E. Klein, D. Manor, J. Biol. Chem, 285 (2010), 35578-35589.

[9] J. Neuzil, K. Kagedal, L. Andera, C. Weber, U.T. Brunk, Apoptosis 7 (2002) 179-187.

[10] G. Cheng, J. Zielonka, D.M. McAllister, A. Craig Mackinnon Jr, J. Joseph, M.B. Dwinell, B. Kalyanaraman, BMC Cancer 13 (2013) 1-14.

[11] R. Gysin, A. Azzi, T. Visarius, FASEB J 16 (2002) 1952-1954.

[12] B.S. McIntyre, K.P. Briski, A. Gapor, P.W. Sylvester, Proc. Soc. Exp. Biol. Med. 224 (2000) 292-301.

[13] S. Salamone, C. Colin, I. Grillier-Vuissoz, S. Kuntz, S. Mazerbourg, S. Flament, H. Martin, L. Richert, Y. Chapleur, M. Boisbrun, Eur. J. Med. Chem. 51 (2012) 206-215.

[14] A. Bordessa, C. Colin-Cassin, I. Grillier-Vuissoz, S. Kuntz, S. Mazerbourg, G. Husson, M. Vo, S. Flament, H. Martin, Y. Chapleur, M. Boisbrun, Eur. J. Med. Chem. 83 (2014) 129140.

[15] C. Cena, D. Boschi, G.C. Tron, K. Chegaev, K.; L. Lazzarato, A. Di Stilo, M. Aragno, R. Fruttero, A. Gasco, Bioorg. Med. Chem. Lett. 14 (2004) 5971-5974.

[16] G.V. López, C. Batthyány, F. Blanco, H. Botti, A. Trostchansky, E. Migliaro, R. Radi, M. González, H. Cerecetto, H. Rubbo, Bioorg. Med. Chem. 13 (2005) 5787-5796.

[17] G.V. López, F. Blanco, P. Hernández, A. Ferreira, O.E. Piro, C. Batthyány, M. González, H. Rubbo, H. Cerecetto, Bioorg. Med. Chem. 15 (2007) 6262-6272.

[18] W. Duan, J. Hou, X. Chu, X. Li, J. Zhang, J. Li, W. Xu, Y. Zhang, Bioorg. Med. Chem. $23(2015) 4481-4488$. 
[19] W. Duan, J. Li, E.S. Inks, C.J. Chou, Y. Jia, X. Chu, X. Li, W. Xu, Y. Zhang, J. Med. Chem. 58 (2015) 4325-4338.

[20] M. Abdel-Aziz, G.E.A.A. Abuo-Rahma, E.A.M. Beshr, T.F.S. Ali, Bioorg. Med. Chem. 21 (2013) 3839-3849.

[21] M.D. Burke, S.L. Schreiber, Angew. Chem. Int. Ed. Engl. 43 (2004) 46-58.

[22] D.A. Horton, G.T. Bourne, M.L. Smythe, Chem. Rev. 103 (2003) 893-930.

[23] L. Constantino, D. Barlocco, Curr. Med. Chem. 13 (2006) 65-85.

[24] B.M. Trost, Science 254 (1991) 1471-1477.

[25] B.M. Trost, Angew. Chem. Int. Ed. Engl. 34 (1995) 259-281.

[26] H.M. Hugel, Molecules 14 (2009) 4936-4972.

[27] M. Ingold, G.V. López, W. Porcal, ACS Sustainable Chem. Eng. 2 (2014), 1093-1097.

[28] A. Dömling, W. Wang, K. Wang, Chem. Rev. 112 (2012) 3083-3135.

[29] R.A. Massarico Serafim, J.E. Gonçalves, F. Pereira de Souza, A.P. de Melo Loureiro, S. Storpirtis, R. Krogh, A.D. Andricopulo, L.C. Dias, E.I. Ferreira, Eur. J. Med. Chem. 82 (2014) 418-425.

[30] L.A. Dutra, L. de Almeida, T.G. Passalacqua, J. Santana Reis, F.A.E. Torres, I. Martinez, R. Gonçalves Peccinini, C.M. Chin, K. Chegaev, S. Guglielmo, R. Fruttero, M.A.S. Graminha, J.L. dos Santos, Antimicrob. Agents Chem. 58 (2014) 4837-4847.

[31] A. Nortcliffe, A.G. Ekstrom, J.R. Black, J.A. Ross, F.K. Habib, N.P. Botting, D. O’Hagan, Bioorg. Med. Chem. 22 (2014) 756-761. 
[32] L. Lazzarato, M. Donnola, B. Rolando, K. Chegaev, E. Marini, C. Cena, A. Di Stilo, R. Fruttero, S. Biondi, E. Ongini, A. Gasco, J. Med. Chem. 52 (2009) 5058-5068.

[33] X. Wanga, L. Wanga, Z. Huang, X. Sheng, T. Li, H. Ji, J. Xu, Y. Zhang, Bioorg. Med. Chem. Lett. 23 (2013) 1985-1988.

[34] M.C. Pirrung, K. Das Sarma J. Am. Chem. Soc. 126 (2004) 444-445.

[35] M.C. Pirrung, K. Das Sarma, Tetrahedron 61 (2005) 11456-11472.

[36] F. Cruz-Acosta, P. de Armas, F. García-Tellado, Chem. Eur. J. 19 (2013) 16550-16554.

[37] P. Cintas, J.L. Luche, Green Chem. 1 (1999) 115-125.

[38] T.J. Mason, Ultrasonics Sonochemistry 14 (2007) 476-483.

[39] A.R. Butler, P. Lightfoot, D.M. Short, J. Org. Chem. 64 (1999) 8748-8749.

[40] R. Boschan, R. Merrow, R.W. Van Dolahi, Chem. Rev. 55 (1955) 485-510.

[41] A.R. Katritzky, Advanced in Heterocyclic Chemistry. Academic Press, 2001.

[42] G. Silveira-Dorta, I.J. Sousa, M.X. Fernandes, V.S. Martín, J.M. Padrón, Eur. J. Med. Chem. 96 (2015) 308-317.

[43] G. Silveira-Dorta, V.S. Martín, J.M. Padrón, Amino Acids 47 (2015) 1527-1532. 